\title{
Rekabet Gücü Kapsamında Dünyadaki ve Türkiye'deki Kentlerin Değerlendirilmesi
}

\author{
Evaluation of Cities of the World and Turkey within the Scope of Competitiveness
}

\author{
Esra ÇELEBI ZENGIN* \\ Hayriye $S A \breve{G} I R^{* *}$
}

\section{$\ddot{O} Z$}

Küresel gelişme ve değişimlerin etkisiyle dünya genelinde siyasi, iktisadi ve idari birçok alanda yeni kavramların benimsendiği bilinmektedir. Kimi zaman özellikle kentte yaşayanlar ve kentler için olumsuz sonuçlar doğurduğu için eleştirilen bu değişim sürecine hâkim olan kavramlardan biri rekabet olarak karşımıza çıkmaktadır. Genellikle özel sektörün vazgeçilmezi şeklinde tanımlayabileceğimiz bu kavramın günümüzde kamu sektörü, kurumları ve personeli açısından da benimsendiği bilinmektedir. Bu noktada artık sadece işletmelerin değil, yönetim birimlerinin ve hatta ülkelerin yarışması gündeme gelmektedir. Yaşanan gelişmeler kapsamında ise bazı kurumlar tarafindan ülkelerin rekabet güçlerini yani rekabet edebilirlik kapasitelerini tespit edebilmek için yıllık endeksleme çalışmaları yapılmaktadır. Şüphesiz ki, ülkeleri etkileyen bu süreçten, kentler de nasibini almaktadır. Dolayısıla kentler için de ulusal ve uluslararası kuruluşlar tarafindan benzer çalışmalar yürütülmektedir. Rekabet gücüne sahip olmanın ekonomik unsurlardan geçtiği gerçeğini esas alan kent yönetimleri ise, yatırımcıyı kente çekme çabalarl ile dikkat çekmektedir. Dolayısıyla yatırımcıyı kente çekebilmenin bir yolu olarak, yerel ve yöresel ayrıcalıklar aracılı̆̆lyla, markalaşma ve rekabet sürecinin kentleri de etkilemeye başladığ bilinmektedir. Marka kent ve girişimci kent kavramları bu etkinin somut bir yansıması olarak literatürde yerlerini almışlardır. Ancak kimi kentlerin markalaşmayı yalnızca küresel firmalara ev sahipliği yapmak şeklinde algıladı̆̆ı da bir gerçektir. Hazırlanan raporlar incelendiğinde ise, bu süreçte tüm kentlerin aynı düzeyde güçlenmediği hatta bölgeler arası eşitsizliğin kentler arasına yayıldı̆̆ı sonucu çıkarılmaktadır.

\section{ANAHTAR KELIMELER}

Kent, küreselleşme, kümelenme, rekabet, rekabet gücü

\section{ABSTRACT}

It is known that new concepts are adopted in the political, economic and administrative fields around the world with the effect of global developments and changes. Sometimes competition is a concept that dominates this process of change, is criticized for having negative consequences especially for the cities and city's inhabitants. It is known that this concept, which can be defined as the indispensable part of the private sector, is now adopted by public sector, institutions and personnel. At this point, not only the enterprises, but also the administrative units and even countries are all in competition. Within the context of this developments, annual indexes are complied by some institutions in order to determine the competitiveness of countries. Undoubtedly, cities are also affected by this process and similar studies are carried out by national and international organizations for cities. Local governments try to attract investors to their cities on the base of the assumption that competitiveness is directly related to economic factors. Therefore, it is known that through the local and regional privileges, the process of branding and competition has begun to affect cities as a way to attract investors. Brand city and entrepreneurial city concepts have taken their places in the literature as a concrete reflection of this effect. However, it is a fact that some cities perceive branding as hosting only global firms. When the reports are analyzed, it is concluded that all cities are not empowered at the same level and even inequalities between the regions are spread among cities.

\section{KEYWORDS}

City, globalization, agglomeration, competition, competitiveness

\begin{tabular}{|c|c|c|}
\hline \multicolumn{2}{|r|}{$\begin{array}{c}\text { Makale Geliş Tarihi / Submission Date } \\
\text { 28.05.2019 }\end{array}$} & $\begin{array}{c}\text { Makale Kabul Tarihi / Date of Acceptance } \\
\text { 11.11.2019 }\end{array}$ \\
\hline Attf & $\begin{array}{l}\text { Zengin, E.Ç. ve Sağır, H. (2019). Rekab } \\
\text { Selçuk Üniversitesi Sosyal Bilimler Me }\end{array}$ & $\begin{array}{l}\text { ünyadaki ve Türkiye'deki Kentlerin Değerlendirilmesi. } \\
i s i, 22(2), 867-889 .\end{array}$ \\
\hline
\end{tabular}

\footnotetext{
* Dr. Öğretim Üyesi, Niğde Ömer Halisdemir Üniversitesi NSBMYO, Yerel Yönetimler Programı, Niğde, esracelebi@ohu.edu.tr, ORCID: 0000-0003-2156-3235

${ }^{* *}$ Dr. Öğretim Üyesi, Selçuk Üniversitesi İ̈BF, Kentleşme ve Çevre Sorunları Anabilim Dalı, Konya, hayriyesamur@selcuk.edu.tr, ORCID: 0000-0003-3302-0203
} 


\section{GİRIŞ}

Güçlü ekonomilerin ve yönetimlerin ayakta kalmayı başardığı ve beraberinde diğer ekonomi ve yönetimleri şekillendirdiği küresel rekabet sürecinde, baş döndürücü bir değişim yaşanmaktadır. Neo-liberal politikaların geçerlilik kazandığı bu değişim sürecinde, hem ulusal değerler hem de devletçi yaklaşımlar büyük hasar görmektedir. Ulusalın yerini yerele, devletçi ekonomilerin yerini özel sermayeye bıraktı̆̆ı günümüz siyasetinde, rekabet kavramı, ülkeleri yarıştırmaya başlamıştır. Değişimin yerelleşme, demokratikleşme, yönetişim ve minimal devlet gibi yeni yaklaşımların benimsenmesiyle gerçekleştiği göz önüne alındığında, yerel yönetimlerin güçlendirildiği ve küreselleşmenin mekânsal yansıması olarak kentlerin öne çıktığı bir süreç yaşanmaktadır. Girişimci kent, marka kent gibi stratejiler ile kent yönetimleri, yaşanan süreçte rekabet avantaj1 yakalamaya çalışmaktadırlar. Ancak bu süreçte tüm kentlerin aynı ilgiyi görmediği, iktisadi, idari ve fiziki açılardan eşit koşullarda bir süreç yaşanmadığı da aşikârdır. Dolayısıyla küresel rekabet olgusuyla şekillenen kentler ile bu durumu firsata çeviremeyen kentler ve kent yönetimleri göz önüne alındığında; bazı kentler belli bir kalkınma ivmesi yakalayıp sosyo-ekonomik yönden önemli avantajlar kazanmakta, diğer kentler aleyhine sürekli büyümektedir. Neticede, bir tarafta kapitalist düzene uygun olarak kurgulanan ve rekabette öncü olmaya çalışan kentler, diğer tarafta ise aynı ülke hatta aynı bölge sınırları içerisinde yer almasına rağmen, sürekli küçülen kentler ortaya çıkmaktadır. Sonuçta ise, kentler arasında derinleşen bir eşitsizlik sorunu yaşanmaktadır. Bu durum, özellikle bölgelerarası eşitsizlik sorunu ile mücadele eden ülkeler açısından, çözülmesi gereken yeni sorun alanları, anlamına gelmektedir. Hem küreselleşme sürecine uyum sağlamaya çalışan, hem de uzun yıllardır bölgeler ve kentler arasındaki gelişmişlik farklılıkları ile mücadele eden Türkiye'de, bu alanlarda yeni politika arayışları içerisindedir.

Tüm ülkeler gibi, Türkiye'de de her alanda etkili olan, rekabet gücü anlayışı ve buna uygun olarak devam eden reform arayışlarının, kentler üzerindeki etkisini incelemek amacıyla, hazırlanan bu çalışmanın ilk bölümünde rekabet ve rekabet gücü kavramları ile, rekabet kavramının ülkeler ve kentler üzerindeki etkisi incelenmiştir. Çalışmanın ikinci bölümünde kentleşme ve kentler arası rekabet konuları, üçüncü bölümünde ise Türkiye'deki kentlerin güncel rekabetçilik düzeyleri ele alınmıştır. Çalışmanın hazırlanmasında, literatür taramasının yanı sıra Dünya Ekonomi Forumu (WEF) tarafından yayımlanan 2017 ve 2018 Küresel Rekabetçilik Raporları, Kalkınma Bakanlığı tarafından hazırlanan; İllerin ve Bölgelerin Ekonomik Gelişmişlik Sıralaması Araştırması (SEGE) ve Uluslararası Rekabet Araştırmaları Kurumu (URAK) tarafından hazırlanan; İllerarası Rekabetçilik Endeksi'nin güncel verileri başta olmak üzere, alandaki diğer çalışmalar da esas alınarak değerlendirme yapılmıştır.

\section{REKABET VE REKABET GÜCÜ}

Küreselleşmenin yansıması olarak her alanda yaşanan rekabetin, özellikle liberal ekonomilerin hâkimiyeti ile stratejik açıdan önemi, sürekli olarak artmaktadır. Bu olgu, günümüz dünyasında sadece işletmelerle sınırlı kalmamakta, yeni sağ akımın öncülügünü yaptığı bir yaklaşımla, kamu yönetimi sistemlerinde de etkin hale gelmektedir. Özellikle ülkeler açısından belirli kriterlerin ölçüt alınarak hazırlandı̆̆ı, rekabetçilik endekslerinde üst sıralarda yer alma çabaları, uygulanan kamu politikalarında da etkisini hızla göstermektedir. $\mathrm{Bu}$ durumda çok boyutlu bir kavram olan rekabet kavramının, sahip olduğu içeriğin kapsamlı olarak ele alınması gerekmektedir.

Türk Dil Kurumu'na göre genel anlamıyla rekabet, "aynı amacı güden kimseler arasındaki çekişme, yarışma, yarış" olarak tanımlanırken, iktisadi anlamda, "herhangi bir etkinlik alanında ayrı ayrı kişi ya da gruplar arasında sürdürülen üstün olma mücadelesi” şeklinde, tanımlanmıştır (TDK, 2018). Türkiye'de 1994 tarihinde yürürlüğe konan, 4054 sayılı Rekabetin Korunması Hakkında Kanun rekabeti, "mal ve hizmet piyasalarındaki teşebbüsler arasında özgürce ekonomik kararlar verilebilmesini sağlayan yarış" şeklinde tanımlamıştır. Tüm bu tanımlara daha geniş bir açıdan bakıldığında ise rekabetin, "belirli bir piyasada çalışan girişimcilerin ekonomik konularda serbestçe karar verebilme hakkı veya kişilerin temel hak ve özgürlüğü olan ticari hayata serbestçe katılma ve ekonomik seçimini özgürce yapma sistemi” (Parlak, 2011: 660) olarak algılandığ1 görülmektedir. Kavram, Rekabet Derneği tarafından ise; "kıt bir şeyi paylaşmak veya bir ödül elde etmek amacıyla belli kural ve kısıtlamalar çerçevesinde, temel özgürlüklerin ve insan haklarının garanti altına alındığı ve hiçbir ayrıcalığın ve ayrımcılı̆̆ın olmadığı bir ortamda, birden fazla oyuncu arasında oynanan bir oyun veya bir yarış" olarak tanımlanmaktadır. Ayrıca, rekabetin "pozitif ayıklama aracı" olarak değerlendirildiği, "iyinin kötüden ayrılması ve iyinin prim yapmasını sağlayan bir mekanizma" (Rekabet Derneği, 2018) olduğu vurgulanmaktadır.

Gelişen ekonominin yarattığı dışsallıkların kontrol altına alınma gerekliliği devletin yeni yönetim anlayışlarına yönelmesi sonucunu doğurmuştur (Acet vd.2014: 507-508). Günümüz koşullarında, başarılı olabilmek adına, yönetim anlayışlarının geleneksel yönetimden farklı olarak rekabet üstünlüğü kazandıran 
stratejik boyuta taşındığı, bundan dolayı da hem ekonomik birimlerin hem de ülkelerin yönetim anlayışlarını ve stratejilerini, rekabet gücü kazandıracak yetenek, kaynak ve değerleri çerçevesinde belirlemeleri, önemli bir zorunluluk haline gelmiştir (Sağır, 2016: 234). Rekabet etmenin aslında bir yarış, bir mücadele, olduğu düşüncesinden yola çıkılırsa, sadece üretmek ve geliştirmek yetmemektedir. Sizin gibi üreten ve daha iyisini yapma imkânı olan rakiplerinizin olduğu ekonomik çevrede, daha iyisini yapmak için faaliyetlerinize ve uygulamalarınıza yön vermek gerekmektedir. Ülke yönetimleri açısından da, küresel ortamda farklı ülkelerle bir yarıştan söz etmek mümkündür. Dolayısıyla bu durumda ülkelerin, yönetsel faaliyetlerini stratejik planlama doğrultusunda yapması ve kaynakların gerekli alanlara kanalize edilip, doğru kullanılması gerekmektedir.

Küresel ekonomide hâkim konumda olabilmek ve hatta ayakta kalabilmek için, ülkeler açısından hayati öneme sahip bir nitelik taşıyan, rekabet gücü kavramının, tanımının yapılması noktasında ise farklı yaklaşımlar söz konusudur. Genel itibariyle, "bir ülkede bir endüstrinin/sektörün diğer ülkelerdeki aynı endüstrilere/sektörlere göre daha yüksek gelir ve istihdam yaratabilme gücü” (Koç ve Özbozkurt, 2014: 86), olarak ifade edilen rekabet gücü kavramının, işletmeler ve ülkeler açısından olmak üzere, iki boyutundan bahsedilmektedir. Ancak rekabet gücü en genel anlamda, Uluslararası Ticaret Merkezi tarafından, 'işletmenin pazarlık gücü, yani müşterilerine mal/hizmetlerin (ürün) miktarı, fiziksel özellikleri, dağıtımı, fiyatı, kalitesi, vs. konularındaki şartlarını dikte edebilme gücü' (Ataç, 2017) olarak tanımlanmıştır. Ayrıca günümüzde kapsamış olduğu alanlar göz önüne alındığında, rekabet gücünün mikro, makro ve bölgesel olmak üzere, farklı biçimlerde değerlendirildiği de dikkat çekmektedir. Bu çerçevede, Kumral (2008) rekabet gücünü, mikroekonomi kapsamında "firmanın rekabet etme, büyüme ve kârlılık konusundaki performansı" olarak, makroekonomik düzeyde ise "serbest ve adil piyasa koşullarında ülkenin, uluslararası piyasalarda kabul gören ürün ve hizmetler üretirken, eş zamanlı olarak vatandaşlarının reel gelirlerini de arttırabilme derecesi” şeklinde, ifade etmektedir.

1970-1980'li yıllarda, pazarların küresel boyutlara ulaşmasıyla birlikte, ülke ekonomileri açısından rekabet gücü, önemli bir kavram olarak algılanmaya başlanmıştır. Böylece, ekonomik yönden güçlü ülkeler başta olmak üzere, her ülke büyüme amacı ile stratejilerini, rekabet üstünlüklerini korumak hatta daha fazla geliştirmek konusunda belirlemiş̧ir (Sağır ve Göktaş 2018: 27). Bu açıdan bakıldığında, merkezi veya yerel yönetimler, mevcut kaynaklarını (doğal kaynak, insan kaynağı, bölgesel değerler ve teknolojiden oluşan alt yap1 vb.) etkili kullanmak suretiyle, rekabet üstünlüğü sağlayabileceklerdir. Bu noktada bölgesel rekabet gücü konusu ile ilgili, bir başka husus, ön plana çıkmaktadır.

Bölgenin, genellikle "kentten geniş, bir ülkenin tamamından daha küçük bir mekân parçası olduğu" ve "bölge ölçeğinin amaçlara göre değiştiği" (Keleş, 2004: 346) gerçeğinden hareketle, bölgesel rekabet gücü ya da bölgesel rekabet edebilirlik, "bir bölge veya şehrin, ulusal ve özellikle de küresel ihraç pazar payında, diğer bölge veya şehirler ile yaptığı rekabetteki başarısı ile birlikte, yüksek ve sürdürülebilir bir gelir düzeyi sağlayabilme yeteneği olarak" (Kitson vd., 2004: 991; Kumral, 2008: 4-5) tanımlanabilmektedir. Başka bir tanımda ise; kavram "bölgelerin bir yandan dış rekabet koşulları içerisinde uluslararası pazarlara yönelik mal ve hizmet üretebilmeleri, bir yandan da bölge içi yüksek ve sürdürülebilir gelir seviyeleri, istihdam oluşturabilmeleri” olarak (URAK, 2016: 14) ifade edilmektedir. Küreselleşmenin ve artan rekabetin etkisi, merkezi ya da yerel yönetimlerin, bölgesel amaçları gerçekleştirirken, insan hakları, çalışma koşulları ve doğal çevre ile ilgili kriterleri, göz önünde bulundurmalarını gerektirmektedir (Sağır ve Türkeri, 2015: 284). Dolayısıyla, bölgelerin teknolojik, sosyal, altyapı (mal ve hizmet üretim kaynakları) ve bölgesel değerler açısından, sahip olduğu faktörlerin, rekabetçi avantaj sağladığı görülmektedir. Ancak rekabet gücünün artırılması bir taraftan bölgedeki ekonomik yapıların güçlendirilmesi ve daha nitelikli iş gücünün çekilmesi konusunda önemli avantajlar sağlarken, diğer taraftan bölgeler arasındaki gelişmişlik farklarını artırıcı etkiler, ortaya çıkarma riskini de beraberinde getirmektedir (Albayrak ve Erkut, 2010: 138-139). Burada en önemli husus, kalifiye işgücü kaybı yaşamaya başlayan bir yerin, zamanla sermayeyi de kaybetmesi neticesinde, gerilemeye başlaması, bunun sonucunda da, kalkınmanın çok zor gerçekleşmesidir. Kalifiye işgücü ve sermayeyi, kendisine çekmeyi başarabilen yerleşimlerde ise, zamanla optimal sınırların aşılması nedeni ile, büyük kente ilişkin yeni sorun alanları, ortaya çıkması muhtemeldir.

\section{DÜNYADA VE TÜRKIYYE'DE REKABET GÜCÜ}

Rekabet gücü kavramının tanımlanmasında, mikro ve makro olmak üzere, iki ölçek üzerinden değerlendirme yapılmaktadır. Buna göre, kavramı mikro ölçekte ele alan yaklaşımda, ülke içinde faaliyet gösteren işletmeler arasındaki rekabet ve bu rekabetin ulusal ya da uluslararası pazardaki etkileri, incelenmektedir. Makro ölçeğe göre yapılan tanımlarda ise, ülkenin uluslararası rekabetteki konumu üzerinde durulmaktadır (akt.: Çivi vd, 2008: 2-3). 
"Rekabet gücü, ülkelerin serbest ve yerleşmiş pazar koşulları altında vatandaşların reel gelirlerini arttırmaya çalışırken, aynı anda ürettiği ürün ve hizmetleri, uluslararası pazarlara sunabilmesi ve başarılı olabilmesidir (akt.: Çivi vd, 2008: 2-3). Rekabet gücü, dört temel göstergeye göre ölçülmektedir. Bunlar (Finance, 2018): İşgücü verimliliği, reel ücret artışı, sektörde istihdam edilen sermaye üzerindeki reel getiri, dünya ticaretindeki pozisyon, şeklindedir. Rekabet gücü, kavramından özel bir alanı içeren bölgesel rekabet gücü kavramı ise, Avrupa Komisyonu'na göre, sektördeki istihdam yoğunlaşması, dış göç ve yaşlı nüfusun fazlalığı, yatırımlar, bölgeye yapılan dolaysız yabancı sermaye yatırımları, bilgi ekonomisi varlıklarına yapılan yatırımlar/yenilikler, altyapı donanımı ve eğitim düzeyi gibi faktörler, tarafından belirlenmektedir (Özer, 2005: 392-393).

Bölgesel açıdan gelişmişlik olgusu, sadece elde edilen gelirle ölçülemez, bu noktada, bölgesel alandaki kentsel yaşam kalitesi (yaşam standartlarının yüksekliği), büyük önem arz etmektedir. Doğal çevrenin korunması, bireylerin çalışma-yaşam alanlarının iyileştirilmesi ve bireylerin haklarının korunacağı ortamın yaratılması da, aynı zamanda bir gelişmişlik ölçüsü, olarak değerlendirilmektedir. Bu doğrultuda bazı kurum ve kuruluşlar tarafından, ekonomiden sağlığa, yaşam kalitesinden teknolojiye kadar, çeşitli kriterler esas alınarak rekabet gücü ölçümlerinin yapıldığ görülmektedir.

\section{1. Ülkeler Bazında Rekabetçilik Düzeyleri}

Günümüz ekonomileri içerisinde, rekabet üstünlüğüne sahip ve öncü konumda olabilmenin, ülkeler açısından taşıdığı önemin, ciddiyeti göz önüne alındığında, ülkelerin rekabet güçlerine ilişkin, somut veriler ortaya koyabilmenin de önemi gittikçe artmaktadır. Bu kapsamda daha önce belirtildiği üzere, çeşitli kurumlar tarafından belirli ölçütlerin kullanılması suretiyle gerçekleştirilen endeksleme çalışmalarının, ilgi görmeye başladığı bilinmektedir. Ancak genel olarak, ekonomik büyüme ve kalkınmaya ilişkin temel göstergeler etrafında şekillenen bu çalışmalarda, sürekliliği ve güncelliği yakalamak ise her zaman mümkün olamayabilmektedir.

Ülkelerin rekabet güçlerinin belirlenmesi, noktasında hazırlanan çalışmalar içerisinde; Dünya Ekonomik Forumu (World Economic Forum-WEF) tarafından yıllık olarak yayınlanan, Küresel Rekabetçilik Raporu, öne çıkmaktadır. 2017-2018 yıllarını içeren rapor; ülkelerin rekabet güçlerinin belirlenmesinde temel gereklilikler, verimlilik arttırıcılar, yenilik ve gelişme faktörleri, olmak üzere üç ana başlık ve 12 temel bileşenden oluşmaktadır. Ancak, kurum tarafından 2018 yılına yönelik, farklı bir metodoloji kullanılarak hazırlanan, Küresel Rekabetçilik Endeksi 4.0'a göre ise, ana başlık ve bileşenlerin tekrar güncellendiği anlaşılmaktadır. Buna göre 4 ana başlık, 12 temel bileşen ve her bir bileşenin farklı sayılarda alt göstergelerinin, bulunduğu belirlenmektedir. Bu çerçevede, etkinleştirici ortam başlığı altında; kurumlar (20), altyap1 (12), BİT'e uyum (5) ve makroekonomik istikrar (2) bileşenleri, incelenmektedir. Beşeri sermaye ana başlığının altında; sağlık (1), yetenekler (9); piyasalar başlığının altında; ürün piyasası (8), işgücü piyasası (12), finansal sistem (9) ve pazar büyüklüğü (2); yenilik ekosistemi başlı̆ğ altında ise; işletme dinamizmi (8) ve yenilik kapasitesi (10) bileşenleri yer almaktadır. Tüm ana ve alt bileşenler dâhilinde, Küresel Rekabetçilik Endeksi 4.0'ın, 98 göstergeyi kapsadığı görülmektedir. Önceki y1l, toplamda 114 bileşenin değerlendirildiği göz önüne alındığında alt göstergelerin sayıca azaltıldığı dikkat çekmektedir. Ayrıca, önceki yıllara göre, puanlamada da bir değişiklik, izlenmektedir. Buna göre; 1 (en düşük) ile 7 (en yüksek) olacak şekilde yapılan puanlama, 0 100 arası değerler üzerinden gösterilmektedir (WEF, 2017a: 317-319, WEF, 2018a: 1-2).

Tablo 1. En Rekabetçi 10 Ülke, 2018 (WEF)

\begin{tabular}{|l|c|c|c|c|}
\hline \multicolumn{1}{|c|}{ İlk 10 Ülke } & $\begin{array}{c}\text { Küresel Rekabetçilik } \\
\text { Endeksi 2018'e Göre } \\
\text { Siralama (140 ülke } \\
\text { içinde) }\end{array}$ & $\begin{array}{c}\text { 2018 Yılı } \\
\text { Rekabetçilik } \\
\text { Puanı }\end{array}$ & $\begin{array}{c}\text { Küresel Rekabetçilik } \\
\text { Endeksi 2017'ye Göre } \\
\text { Suralama (137 ülke } \\
\text { içinde) }\end{array}$ & $\begin{array}{c}\text { 2017 Yılı } \\
\text { Rekabetçilik } \\
\text { Puanı }\end{array}$ \\
\hline ABD & 1 & 85.6 & 2 & 5.85 \\
\hline Singapur & 2 & 83.5 & 3 & 5.71 \\
\hline Almanya & 3 & 82.8 & 5 & 5.65 \\
\hline İviçre & 4 & 82.6 & 1 & 5.86 \\
\hline Japonya & 5 & 82.5 & 9 & 5.49 \\
\hline Hollanda & 6 & 82.4 & 4 & 5.66 \\
\hline Hong Kong SAR & 7 & 82.3 & 6 & 5.53 \\
\hline İngiltere & 8 & 82.0 & 8 & 5.51 \\
\hline İseç & 9 & 81.7 & 7 & 5.52 \\
\hline Danimarka & 10 & 80.6 & 12 & 5.39 \\
\hline
\end{tabular}

Kaynak: WEF, 2018a: xi; WEF, 2017a:ix. 
Tablo.1'de yer alan veriler incelendiğinde, rekabet gücü en yüksek ülkelerin; Avrupa ve Kuzey Amerika ile Doğu Asya ve Pasifik ülkelerinden, oluştuğu görülmektedir. Raporlar incelendiğinde; puanlama alt ve üst eşiklerinde bir değişikliğe gidildiği anlaşılmaktadır. Buna göre; 2017 de dâhil tüm raporlara ait puanlama 1-7 arasında yapılırken, 2018' de bu değerlerin 0-100 arasında dağılım sergilediği anlaşılmaktadır (WEF, 2018a: xi; WEF, 2017a: ix). Sıralama açısından önemli farklılıkların yaşanmadığı tespit edilen tabloda, rekabetçilikte genel itibariyle, aynı ülkelerin lider konumda olduğu görülmektedir. Burada üst üste iki yıl birinciliği elinde bulunduran, İsviçre'nin 3 sıra birden gerileyip 4. ülke konumuna yerleştiği dikkat çekmektedir. Ayrıca Japonya ve Danimarka'nın, durumlarında ilerleme kaydedildiği, tespit edilmektedir. Buna göre bir önceki yıla göre, Japonya'nın 9. sıradan 5. sıraya yükseldiği ve 2017 yılında ilk 10 sıralamasında yer almayan Danimarka'nın, 2018'de iki sıra ilerleyerek, ilk 10 ülke içinde yer almayı, başardığı görülmektedir.

Tablo 2. Rekabet Gücü En Düşük 10 Ülke (WEF)

\begin{tabular}{|l|c|c|c|c|}
\hline Son 10 Ülke & $\begin{array}{c}\text { Küresel Rekabetçilik } \\
\text { Endeksi 2018'e Göre } \\
\text { Siralama (140 ülke } \\
\text { içinde) }\end{array}$ & $\begin{array}{c}\text { 2018 Yılı } \\
\text { Rekabetçilik } \\
\text { Puanı }\end{array}$ & $\begin{array}{c}\text { Küresel Rekabetçilik } \\
\text { Endeksi 2017'ye Göre } \\
\text { Siralama (137 ülke } \\
\text { içinde) }\end{array}$ & $\begin{array}{c}\text { 2017 Yılı } \\
\text { Rekabetçilik } \\
\text { Puanı }\end{array}$ \\
\hline Moritanya & 131 & 40.8 & 133 & 3.09 \\
\hline Liberya & 132 & 40.5 & 134 & 3.08 \\
\hline Mozambik & 133 & 39.8 & 136 & 2.89 \\
\hline Sierra Leone & 134 & 38.8 & 130 & 3.20 \\
\hline $\begin{array}{l}\text { Demokratik } \\
\text { Kongo Cumh. }\end{array}$ & 135 & 38.2 & 126 & 3.21 \\
\hline Burundi & 136 & 37.5 & 129 & n/a \\
\hline Angola & 137 & 37.1 & 129 & 3.22 \\
\hline Haiti & 138 & 36.5 & 137 & 2.87 \\
\hline Yemen & 139 & 36.4 & 135 & 2.99 \\
\hline Çad & 140 & 35.5 & & \\
\hline
\end{tabular}

Kaynak: WEF, 2018a: xi; WEF, 2017a: ix.

Endeks bazında belirlenen rekabet gücü, en düşük 10 ülke, Tablo.2'de görüldüğü gibi, Haiti ve Yemen hariç, genel itibariyle Sahraaltı Afrika ülkelerinden oluşmaktadır. Tabloda yer alan veriler incelendiğinde, önceki yıl 128. sırada yer alan Haiti'nin, 10 sıra birden gerileyip, 138. sıraya düştüğü anlaşılmaktadır. Haiti'yi, bir önceki yıla göre 9 sira birden gerileyen, Demokratik Kongo Cumhuriyeti ile, 7 sira birden gerileyen Burundi, izlemektedir. Bir önceki yıla göre, yeni ülkelerin listeye alınıp, ülke sayısının 137'den 140'a çıkarıldığı göz önüne alındığında, önceki yıl listede yer almayan Angola'nın 37.1 puanla 137. sıradan listeye girdiği, görülmektedir. Rekabet güçlerinde, önceki yıla göre artı̧ yaşandığı, konumlarındaki iyileşmeden anlaşılan ülkeler ise; Moritanya, Liberya ve Mozambik’tir. Buna göre, Mozambik, 3 sıra ilerleyerek 136. sıradan 133. sıraya; Liberya 2 sira yükselerek 132. siraya ve Moritanya da 2 sira yükselerek 131. siraya yükselmiştir.

WEF gibi, hazırlamış olduğu yıllık rekabetçilik raporları ile öne çıkan, bir diğer küresel kurum olan Uluslararası Yönetim Geliştirme Enstitüsü (International Institute of Management Development- IMD) tarafından yayımlanan, Dünya Rekabetçilik Yıllığı'nda ise, ülkelerin rekabetçilik sıralamalarının değiştiği görülebilmektedir.

Tablo. 3 IMD’ye göre En Rekabetçi 10 Ülke (2018)

\begin{tabular}{|c|c|c|c|}
\hline Ülke & $\begin{array}{c}\text { Ülke } \\
\text { Siralaması } \\
\text { (2018 yılı) } \\
\end{array}$ & $\begin{array}{c}2018 \text { yılı } \\
\text { Rekabetçilik } \\
\text { Puanı } \\
\end{array}$ & $\begin{array}{c}\text { Ülke } \\
\text { Siralaması } \\
(2017 \text { yılı) } \\
\end{array}$ \\
\hline ABD & 1 & 100.000 & 4 \\
\hline Hong Kong SAR & 2 & 99.162 & 1 \\
\hline Singapur & 3 & 98.553 & 3 \\
\hline Hollanda & 4 & 97.534 & 5 \\
\hline İsviçre & 5 & 97.143 & 2 \\
\hline Danimarka & 6 & 96.385 & 7 \\
\hline Birleşik Arap Emirlikleri & 7 & 95.659 & 10 \\
\hline Norveç & 8 & 95.424 & 11 \\
\hline İsveç & 9 & 95.046 & 9 \\
\hline Kanada & 10 & 94.337 & 12 \\
\hline
\end{tabular}

Kaynak: IMD, 2018: 1 . 
Tablo.3'teki sıralama incelendiğinde, ilk 10'da yer alan ülkelerden, 7'sinin WEF tarafından da ilk siralarda yer alan ülkeler arasında sayıldığı belirlenmektedir. Her ne kadar ABD ve İsveç haricindeki diğer ülkelerin sıralamadaki konumları değişse de, yüksek rekabet gücüne sahip olan ülkelerin çoğu, her iki kurum tarafından da benzer şekilde, değerlendirilmektedir. Buna göre ABD, Hong Kong SAR, Singapur, Hollanda, İsviçre, Danimarka ve İsveç'in rekabetçilik seviyesi en yüksek, ülkeler olduğu; hem IMD hem de WEF tarafından kabul görmektedir. Özellikle ABD, yine her iki kurum tarafından lider ülke konumunda gösterilmektedir. Dolayısıyla 2018 yılında, dünyanın en rekabetçi ülkesine ilişkin iki kurumun da ortak tespiti, ABD olarak belirlenmektedir. İsveç ise, hem IMD hem de WEF tarafından 9. sırada konumlanmıştır. IMD'nin ilk 10 sıralamasında en çok dikkat çeken nokta ise, bir Ortadoğu ülkesi olan Birleşik Arap Emirlikleri'nin 7. sırada yer almasıdır. Bu ülke WEF'in 2018 raporunda, 27. sırada yer almaktadır (WEF, 2018a: xi; IMD, 2018: 1).

Tablo. 4 IMD’ye Göre Rekabet Gücü En Düşük 10 Ülke (2018)

\begin{tabular}{|c|c|c|c|}
\hline Ülke & $\begin{array}{l}\text { Ülke Siralaması } \\
\text { (2018 yilı) }\end{array}$ & $\begin{array}{c}2018 \text { yllı Rekabetçilik } \\
\text { Puanı }\end{array}$ & $\begin{array}{l}\text { Ülke Siralaması } \\
\text { (2017 yılı) }\end{array}$ \\
\hline Peru & 54 & 60.236 & 55 \\
\hline Slovak Cumh. & 55 & 60.037 & 51 \\
\hline Arjantin & 56 & 57.986 & 58 \\
\hline Yunanistan & 57 & 57.375 & 57 \\
\hline Kolombiya & 58 & 57.357 & 54 \\
\hline Ukrayna & 59 & 56.763 & 60 \\
\hline Brezilya & 60 & 55.797 & 61 \\
\hline Hirvatistan & 61 & 55.344 & 59 \\
\hline Moğolistan & 62 & 52.616 & 62 \\
\hline Venezüella & 63 & 27.509 & 63 \\
\hline
\end{tabular}

Kaynak: IMD, 2018: 2

Rekabet gücü en düşük 10 ülke, esas alındığında ise, Tablo.3’teki uyumun bulunmadığı anlaşılmaktadır. Hesaplamaya dâhil edilen ülke sayısının, WEF' in hesapladığı ülke sayısının yarısından daha az olduğu dikkate alındığında, bu durum normal karşılanmaktadır. Her iki sıralama karşılaştırıldığında; Tablo. 4 'teki ülkelerin konumu, 140 ülkenin değerlendirildiği; WEF Küresel Rekabetçilik Endeksi 4.0'a göre oldukça değişmektedir. Örneğin IMD'ye göre; 63. yani son sırada yer alan Venezüella, 127. sırada; 56. sirada bulunan Arjantin 81. sırada; 59. sırada yer alan Ukrayna ise, 83. sırada bulunmaktadır. Burada en çok dikkat çeken ülke ise, Slovakya Cumhuriyeti'dir. Çünkü IMD'nin yaptığı sıralamada rekabet gücü en düşük 10 ülkeden biri olan Slovakya Cumhuriyeti, WEF'in sıralamasında 140 ülke içinde 41. sırada bulunmaktadır (WEF, 2018a: xi; IMD, 2018: 2).

\subsection{Rekabet Gücü Kapsamında Türkiye}

Karşı karşıya kalmış olduğu, ekonomik ve siyasi gelişmeler nedeniyle dünya kamuoyunda sıklıkla yer bulan Türkiye de, dünya ülkeleri ile rekabet yarışında, bulunmasıyla dikkat çekmektedir. Ancak ülkenin rekabetçilik düzeyinin sabit kalmadığı ve genellikle inişli-çıkışlı olduğu belirlenmektedir. Hatta bu durumun genel olarak iniş, yani gerileme lehinde olduğu da, WEF Raporu esas alınarak anlaşılmaktadır.

Tablo.5 Yıllar İtibariyle Türkiye'nin Rekabetçilik Düzeyi

\begin{tabular}{|c|c|c|c|}
\hline Yıllar & $\begin{array}{c}\text { Hesaplamaya Dâhil } \\
\text { Edilen Ülke Sayısı }\end{array}$ & $\begin{array}{c}\text { Türkiye'nin } \\
\text { Sıralamadaki Yeri }\end{array}$ & $\begin{array}{c}\text { Türkiye'nin Ülke } \\
\text { Puanı (yaklaşı) }\end{array}$ \\
\hline $2012-13$ & 144 & 43 & 4.5 \\
\hline $2013-14$ & 148 & 44 & 4.5 \\
\hline $2014-15$ & 144 & 45 & 4.5 \\
\hline $2015-16$ & 140 & 51 & 4.4 \\
\hline $2016-17$ & 138 & 55 & 4.4 \\
\hline $2017-18$ & 137 & 53 & 4.4 \\
\hline $2018^{1}$ & 140 & 61 & 62 \\
\hline
\end{tabular}

Kaynak: WEF, 2017b:1; WEF, 2018b: 1.

\footnotetext{
${ }^{1}$ WEF tarafından, 2018 yılında Küresel Rekabetçilik Endeksi 4.0 2018, başlığı ile yeni bir rapor daha yayımlanmıştır. Ayrıca daha önce belirtildiği üzere, önceki raporlarda değerlendirmede 1-7 arası puanlar belirlenmişken, 2018'de yayınlanan bu raporda 0-100 arası değerler üzerinden sonuçlar hesaplanmıştır.
} 
Küresel Rekabetçilik Raporu'na göre, Avrupa ülkeleri arasında kategorize edilen Türkiye, 2018 yılında endekse dâhil edilen 140 ülke arasında; 61.6 puan ile 61. sırada yer almıştır (WEF, 2018a, xi). Raporun 20172018 olarak yayınlanan, önceki yıla ait verilerinde; ülkenin 2017 yılında 137 ülke arasında 4.42 puan ile 53. sırada yer aldığı (WEF, 2017b, ix) görülmektedir. Raporun ilk kez yayınlanmaya başladığı 2012-2013 yılından itibaren ülkenin konumu değerlendirildiğinde, Türkiye'nin 2017-2018 dönemi haricinde, diğer tüm y1llarda, gerileme eğilimi, sergilediği tespit edilmektedir (WEF, 2017b: 1).

Raporda nüfusu 80.8 milyon kişi, kişi başına düşen GYSIH'sı ise 10,512.0\$ olarak belirtilen (WEF, 2018b: 1) Türkiye'nin, rekabet gücüne ilişkin kategorilerden aldığ Tablo. 6'da yer verilmiştir.

Tablo.6 Endeks Bazında Türkiye’nin Rekabetçilik Düzeyi (2018)

\begin{tabular}{|l|c|c|}
\hline \multicolumn{1}{|c|}{ Bileşenler } & Puan (0-100 arası) & $\begin{array}{c}\text { Diğer Ülkeler } \\
\text { İçindeki Sıralaması }\end{array}$ \\
\hline Kurumlar & 52,9 & 71 \\
\hline Altyapı & 72.6 & 50 \\
\hline BंT'e uyum & 53,5 & 71 \\
\hline Makroekonomik istikrar & 67.4 & 116 \\
\hline Sağlık & 86.2 & 48 \\
\hline Beceriler & 60.5 & 77 \\
\hline Ürün piyasası & 55.2 & 76 \\
\hline İş̧ücü piyasası & 51.2 & 111 \\
\hline Finansal sistem & 59.9 & 65 \\
\hline Pazar büyüklüğ̈̈ & 78,5 & 13 \\
\hline İşletme dinamizmi & 57.2 & 76 \\
\hline Yenilik kabiliyeti & 44.0 & 47 \\
\hline
\end{tabular}

Kaynak: WEF, 2018b: 1.

Tablo.6' da yer alan veriler incelendiğinde; belirlenen 12 bileșen kapsamında Türkiye'nin, sahip olduğu en yüksek puanın 86.2 ile sağlık, en düşük puanın ise 44.0 ile yenilik kabiliyeti, bileşenine ait olduğu görülmektedir. Endüstri 4.0 olarak tanımlanan, dördüncü sanayi devrimi, ülkeleri çok farklı boyutlarda etkileme potansiyeline sahiptir. Hızlı bir değişim sürecini beraberinde getiren bu devrimde, ülkelerin küresel sistemde değişime ayak uydurabilmek, başarılı olabilmek ve ayakta kalabilmek adına, önem vermeleri gereken en önemli alan, yenilik kabiliyetlerini güçlendirmektir. Yenilik kabiliyeti, günümüz dünyasında sürdürülebilir bir rekabet avantajı yakalamada, stratejik öneme sahiptir. Yenilik kabiliyetinde, gerçekleştirilmesi için gereken politika düzenlemelerinin yapılması, ülkemiz açısından büyük önem arz etmektedir. Türkiye'nin diğer ülkeler içindeki konumunun, ülkenin rekabet gücünün değerlendirilmesi açısından önemli olduğu esas alındığında, tabloya ilişkin yeni yorumlar yapmak da mümkün olabilmektedir. Bu doğrultuda, Türkiye'nin pazar büyüklügü bileşeninde, 78.5 puana sahip olduğu görülmektedir. Aldığı puan, ülkeyi 140 ülke arasından 13. sıra gibi yüksek bir sıraya yerleştirmiş bulunmaktadır. Ancak son aylarda, ülke gündemini de oldukça meşgul eden ekonomik durumun bu rapora yansıması da olumlu görünmemektedir. Sahip olduğu 67.4 puana rağmen Türkiye, makroekonomik istikrar bileşeninde 140 ülke arasından 116. sırada bulunmaktadır. Belirtilen değerler kapsamında, ülkenin rekabet gücünün en yüksek olduğu alan; pazar büyüklüğü, en düşük olduğu alan ise; makroekonomik istikrardır. 


\section{Grafik. 1 Türkiye'de İş Yaşamında Karşılaşılan En Problemli Unsurlar}

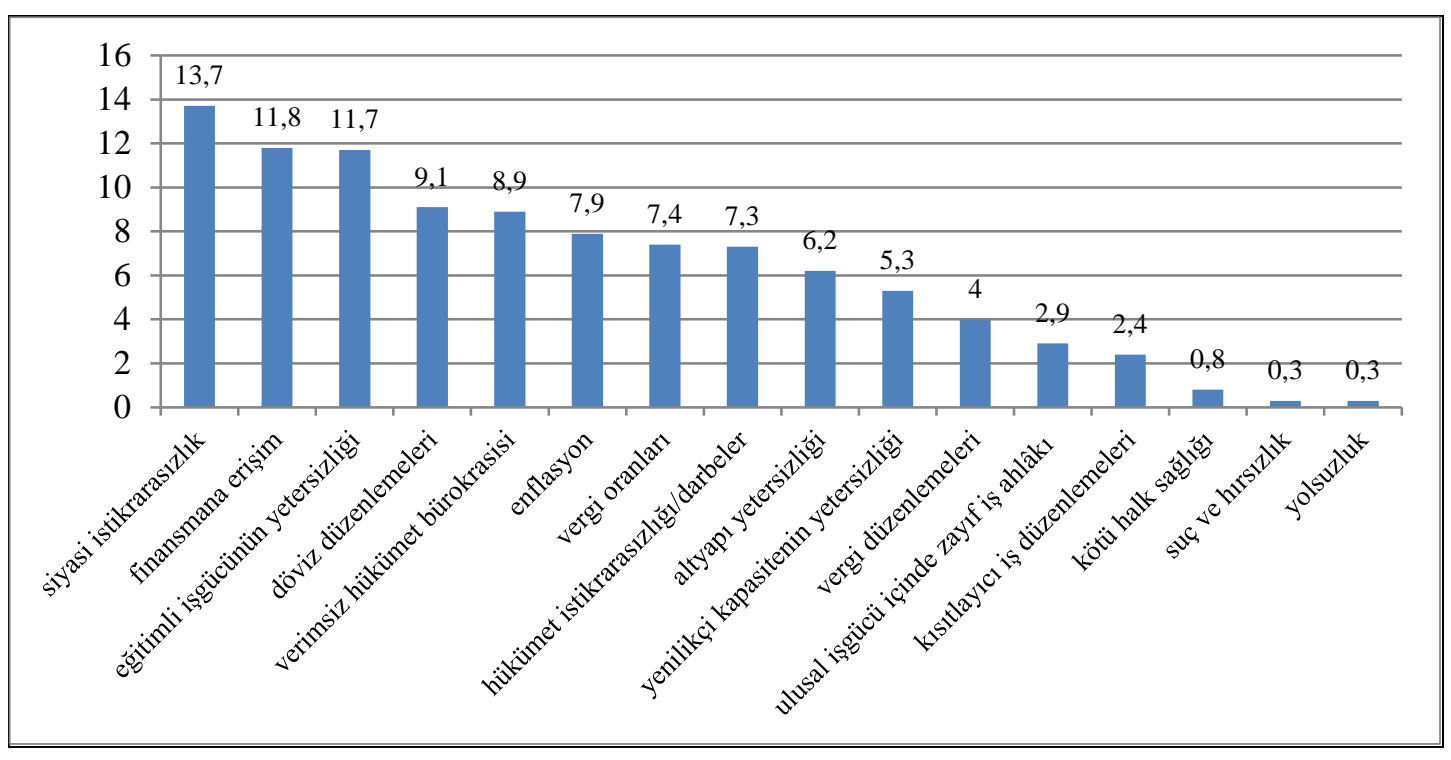

Kaynak: WEF, 2017c: 2.

Türkiye'de, iş hayatında karşılaşılan en problemli konular; siyasi istikrarsızlık, finansmana erişim, eğitimli işgücünün yetersizliği, döviz düzenlemeleri, verimsiz hükümet bürokrasisi, enflasyon, vergi oranları, hükümet istikrarsızlığı/darbeler, altyapı yetersizliği, yenilikçi kapasitenin yetersizliği, vergi düzenlemeleri, ulusal işgücü içinde zayıf iş ahlakı, kısıtlayıcı iş düzenlemeleri, kötü halk sağlığı, suç ve hırsızlık, yolsuzluk, başl1kları altında, 2017-2018 Küresel Rekabetçilik Raporu'nda, değerlendirilmiştir. Yine WEF tarafından, 2016 yılında gerçekleştirilen yönetici görüşleri, anketine ilişkin veriler, Grafik.1'de belirtilmektedir. Buna göre Türkiye'de iş dünyasının karşılaştığı en problemli alanların başında; siyasi istikrarsızlığın geldiği görülmektedir. Finansal, yönetsel ve liyakate ilişkin diğer sorunlarda, yine öncelikli sorun alanlarını işaret etmektedir. Meslek etiği, kısıtlayıcı iş düzenlemeleri, suça ve topluma ilişkin unsurlar ise, katılımcılar tarafından düşük payı olan sorunlar olarak görülmektedir.

IMD tarafından ekonomik performans, hükümetin verimliliği, iş verimliliği ve altyap1, olmak üzere dört temel bileşene göre hazırlanan ve 63 ülkenin sıralamasının yapıldı ̆̆ı, Dünya Rekabetçilik Yıllığı'nda ise Türkiye, sahip olduğu; 66.607 puan ile, 46. sırada yer almaktadır. Bu endeks kapsamında 2017 yılında 47. sırada bulunan ülkenin, önceki yıla göre ilerleme kaydettiği görülmektedir (IMD, 2018: 2).

\section{DÜNYA KENTLERİIIN REKABET EDEBİLİRLİ̆İ}

21.yüzyılın başından itibaren, gelişmiş ülkelerde ekonomik faaliyetlerde ortaya konulacak birtakım yenilikler, önemli bir zorunluluk haline gelmiştir. Bu doğrultuda küreselleşme sonrasında, ekonomik kalkınmanın kritik ajanları olarak nitelendirilen kentlerde, inovatif ve gelişmiş sanayilerin gelişmelerine imkân oluşturacak ortamlar oluşturulmaya çalışılmıştır. Küreselleşme, ekonomik rekabeti kentler açısından, daha yoğun bir hale getirmiştir. Böylece, rekabetçilik üzerine yapılan araştırmalar ve çalışmalar kentlere doğru yönelerek, kentlerin rekabetçilikte üstlenmiş oldukları roller ve bunlara etki eden faktörler tespit edilmeye çalışılmıştır (Eroğlu ve Yalçın, 2014: 25). Üretim sürecinde yaşanan değişimler de, kentlerin rekabet avantajı yakalamalarında, önemli bir etkendir. Daha esnek bir üretim sürecine geçilmesi, küçük ve orta ölçekli işletmelerin de küreselleşme sürecinde önemli bir avantaj kazanmalarına neden olmuştur. KOBİ'lerin böyle bir avantaj kazanmaları, bulundukları kentleri de avantajlı bir konuma taşımıştır.

1991 yılında Garreau (akt, Henderson \& Mitra,1996: 613-614) tarafından yazılan, Üstün Şehirler Kitabı, teknolojik gelişmeler sayesinde, Amerikan kentlerinde yaşanan değişimi anlatmaktadır. Bu kentler 1960'lı yılların ikinci yarısından itibaren büyük ve merkezi kentlerin dışında, oluşturulan yeni kentlerdir. Sakinleri için iş, konut, alışveriş ve hizmet sektörüne ilişkin tüm imkânlara sahip olan söz konusu kentlerde yer alan işletmelerde, yapılan üretim, zekice planlanan bilgi çağının fabrikalarında gerçekleştirilmektedir. Ele alınan kentler, banliyöleşme ve kentsel yayılma konusunda; kentsel literatüre farklı bir bakış açısı, kazandırmıştır. Söz konusu büyükş̧ehir bölgelerindeki, üretimin mekânsal organizasyonu ve ticaret bölgesinin nasıl 
konumlandırılması, gerektiği hususunda yeni bir bakış açısı ortaya koymuştur (Henderson \& Mitra, 1996: 614).

Elektronik ticaretin yaygınlaşması, işletmelerin önündeki mekân kısıtını ortadan kaldırmıştır. Küreselleşme ile birlikte uluslararası ticarette yaşanan engellerin ortadan kalkması, küçük yerleşme yerlerinde faaliyette bulunan işletmelerin daha önce karşı karşıya kaldıkları pazarlama güçlüklerini aşmalarına, olanak sağlamıştır (Karakılçık, 2014: 71). Sonuçta; büyük sanayi merkezleri dışında kalan küçük yerleşimlerde yer alan KOBI'ler, gelişmiş sanayilerde bulunan büyük işletmelerle üretim kalitesi, maliyet, pazarlama olanakları yönünden, rekabet avantajı yakalayabilmiştir. Böylece birçok ülkede yeni sanayi merkezleri ortaya çıkmıştır. Ülkemizde Anadolu Kaplanları olarak adlandırılan; Denizli, Gaziantep, Kahramanmaraş başta olmak üzere 12 kent, esnek üretim sisteminin sağlamış olduğu imkânları avantaja çevirmeyi başarabilmiş kentlerdir. Bu doğrultuda, aşırı kalabalıklaşmış büyük merkezler cazibesini yavaş yavaş yitirirken, büyük kentlerin çevresi gelişmeye başlayacak ve KOBİ'lerin faaliyet gösterdikleri optimum ölçekli, daha az çevresel sorunun olduğu yeni kentler ön plana çıkacaktır (Dinler, 2016: 121). Belli bir bölgede yaşanan ekonomik gelişmenin, ileri düzeylere taşınabilmesi iki etmenle açıklanmaktadır; ilk olarak ölçek ekonomilerinden azami derecede faydalanmak isteyen işletmeler, üretim kapasitelerini en uygun seviyeye ulaştırmak amacıyla yeni yatırımlar gerçekleştirecektir ki, bu da bulunduğu bölgedeki ekonomiyi de canlandıracaktır. İkinci olarak da, işletmeler dışsal ekonomilerden faydalanmak amacıyla, aynı bölgede toplanmayı tercih edeceklerdir (Karakılçık, 2014: 71). Kuruluş yerinin sunmuş olduğu avantajlar, ulaşım kolaylıkları, yerel girişim ruhu, teknolojik gelişme, buluşların mekânsal dağılımından elde edilecek karşılaştırmalı üstünlükler, içsel ve dışsal ekonomiler, altyapı yatırımları, organize sanayi bölgeleri, teknokentler, teşvikler, işletmelerin yapacakları mekânsal tercihlerde önemli faktörler olarak rol almaktadır (Öztürk ve Uzun, 2010: 94). Bu tercihte de işletmelere sunulacak imkânlar, kentlerin sahip olduğu avantaj ve dezavantajlar noktasında, kentler birbirleriyle rekabet edeceklerdir.

Her ne kadar tarih boyunca, kentler birbirleri ile bir rekabet içinde olsalar da, kent rekabetçiliği kavramı son birkaç on yılda ortaya atılan bir kavramdır. Küreselleşmenin kentler üzerinden hayat bulması rekabet kavramının kentsel mekânı kapsaması sonucunu doğurmuştur. Burada iki husus öne çıkmaktadır; öncelikle, yerel yönetimlerin sorumluluklarının, sadece kamu hizmeti sunumuyla sınırlı olamayacağı anlaşılmıştır. İkinci husus ise, yerel girişimciliğin geliştirilmesinin de, hizmet sunumuna dâhil edilmesi gerekliliği ve 1970'li yıllarda başlayan seri üretim krizi ile birlikte, sanayi kentlerinde ortaya çıkan sorunların çözümlenmesi ihtiyacıdır. Kentsel rekabet konusunda yapılan çalışmaların çoğunluğu, kentin sosyo-ekonomik gelişiminde ekonomik çeşitliliğin önemini vurgulamaktadır (Lember vd., 2011: 1374-1375). Kent rekabetçiliğinin stratejik bir bakış açısıyla ele alındığı, ilk önemli çalışma, 1995 yılında Michael Porter tarafindan hazırlanan belirli ölçekler geliştirerek kentlerin rekabet gücünü ölçmeye yönelik "The Competitive Advantage Of The Inner City" başlıklı makaledir (Döven, 2013: 190). Porter makalesinde, kentin içindeki ve çevresindeki ekonomik faaliyetlerin rekabet avantajına sahip olmasının, başka yerleşimlerde gerçekleştirilmesi zor olan bir işi kapsarsa, orada kalıcı bir avantaj yakalayacağını vurgulamaktadır. Porter'a göre, eğer şirketler kentsel bir tercihte bulunacaklarsa, onları kent içine yerleştirmek için zorlayıcı bir rekabet nedeni, bulmaları gerekmektedir. Konuyla ilgili olarak, makalede elektronik sektöründe hizmet veren Alpha Şirketi'nin, New York kentinde gerçekleştirmiş olduğu başarı örnek gösterilmektedir. Şirket başlangıçta Manhattan'da kurulmuştur, 1987 yılında New York Ekonomik Kalkınma Ofisi, şirketlerin mekânsal yerleşimleri ile ilgili bir düzenleme (makalede bu düzenleme ekonomik bir Rönesans olarak ifade edilmektedir) gerçekleştirmiştir. Düzenleme sonrasında kentin, bu yüksek teknoloji şirketi sayesinde, sıkıntılı bir mahallesi, istikrara kavuşmuştur. Bununla birlikte, bölgede yeni istihdam imkânları da ortaya çıkmıştır. Gerçekleştirilen mekânsal düzenleme sayesinde kent, Alpha şirketinin maliyetlerini düşürmesine ve kârını artıracak sayısız teşvikler elde etmesine imkân sağlamıştır. Bu örnek, Porter tarafından, ideal bir strateji olarak ifade edilmektedir. Ancak bu durum 1994 yılında tersine dönmüştür, nitelikli işgücünü bulunduğu bölgeye çekemeyen ve yerel sakinleri eğitemeyen şirket, üretimini ve bazı tasarım çalışmalarını dış kaynak, olarak kullanmak zorunda kalmıştır. Bununla birlikte, şirketin bulunduğu mekânla ilgili olarak ortaya çıkan, güvenlik problemleri, şirketin zor duruma düşmesine sebep olmuştur. Alpha Şirketi'nin yaşamış olduğu bu deneyim, bir işletmenin başarı veya başarısızlığında mekânsal konumun, ne kadar kritik, olabileceğini göstermektedir. Her yerleşim birimi, şirketlerin belirli bir alanda rekabet etme kabiliyetini destekleyen, bir dizi benzersiz yerel imkânlara sahiptir. Rekabet avantajı genellikle izole şirketlerle değil, aynı sektörde hizmet veren müşteri, tedarikçi gibi birtakım ilişkiler yoluyla birbirine bağlanan şirketler aracılı̆̆ ile ortaya çıkmaktadır. Kümeler, belirli bir alanda kritik beceri, bilgi, ilişki ve altyapı kitlelerini temsil etmektedir. Bir mekândaki rekabetçi şirketlerin varlığı yeni tedarikçilerin oluşmasına, ilgili alanlarda şirketlerin büyümesine, özel eğitim programlarının oluşturulmasına ve üniversitelerde, teknolojik mükemmeliyet merkezlerinin, ortaya çıkmasına katkıda bulunmaktadır. Bununla birlikte kümeler, kendilerine yeni katılanlara, kendi ekonomik avantajları konusundaki deneyimlerinden 
öğrenebilecekleri ve yararlanabilecekleri uzmanlığa, bağlantılara ve altyapıya erişme imkânı da sağlamaktadırlar (Porter, 1995). Bu doğrultuda kent içi rekabet avantajları ve işletmelerin çevredeki kent ve bölge ekonomileri ile bağlantı kurma yolları önem kazanmaktadır. Porter (1995), tarafindan bu avantajlar; stratejik konum, yerel pazar talebi, bölgesel kümelenmelerle entegrasyon ve insan kaynakları olarak belirtilmektedir.

2001 yılında Huovar ve arkadaşları tarafindan, Finlandiya'daki bölgelerin rekabetçilik endekslerini hesaplamaya yönelik geliştirilen çalışma da literatürdeki ilk örnekler, arasında yer almaktadır. Aynı dönemde Deas ve Giordano tarafından, İngiltere'de 17 büyük kentin rekabetçilik düzeyini ölçmeye yönelik bir başka çalışma daha yapılmıştır (Döven, 2013: 190-195). Krugman ise çalışmalarında, kent rekabetçiliğini eleştirel bir çerçeveden ele almıştır. Rekabetçiliğin, ancak firma düzeyinde olabileceğini ifade ederek, uluslararası ticaretin, karşılıklı yarar değişiminden ibaret olduğunu savunmuştur. Eleştirilerine dayanak olarak, ileri sürmüş olduğu argümanlar ise şu şekildedir (Krugman 1994-1996'dan akt, Eroğlu ve Yalçın, 2014: 27-28);

- Ülkeler ile firmalar arasında benzerlik kurulamaz, çünkü; başarısız firmalar iş hayatından çekilirler, ancak ülkeler için böyle bir durum söz konusu değildir.

- Firmalar pazar payı elde etmek için rekabet ederler ve birinin kaybetmesi diğerinin kazanması anlamına gelmektedir. Oysaki bir bölge ya da ülkenin başarısı, diğerlerinin başarısına bir engel teşkil etmemektedir; hatta yeni olanaklar ortaya çıkarma ihtimali bile bulunmaktadır.

- Ülkeler arası ticaret, sıfir toplamlı bir oyun değildir, rekabet edilebilirlik bir anlama sahipse, bu üretkenliğin farklı bir şekilde ifadesi olarak, ele alınabilir. Ulusal ölçekte yaşam standartlarındaki gelişme, temelde verimlilik artış oranı ile bağlantılıdır.

Kent rekabetçiliği alanındaki çalışmaların, 2000'li yılların başlarından itibaren ulusal ve uluslararası arenada yaygınlaştığı dikkat çekmektedir. Burada küreselleşme önemli bir etken olarak değerlendirilebilir, çünkü küreselleşme kentler üzerinden beslenmektedir. Kentler de küresel ekonomi ile bütünleştikleri ölçüde önem kazanmakta ve cazibe merkezi durumuna gelmektedirler. Belirli bir konuda rekabet avantajı yakalamay1 başarmış kentlerin, bunu sürdürülebilir bir seviyeye taşımaları bölgelerinde bir kalkınma kutbu oluşturabilmelerine bağlıdır.

Küreselleşmenin ve sermaye hareketlerindeki artışın hız kazanmasına paralel olarak, alandaki çalışmaların artması da olağan bir sonuç gibi durmaktadır. Dolayısıyla rekabetin ülkeleri, ekonomileri, bölgeleri yarıştırdığı günümüz dünyasında, bazen tek bir kentin bazen ise, aynı ülkedeki birden çok kentin, diğer kentlere kıyasla daha avantajlı olduğu görülmektedir. Bu noktada belirtmek gerekir ki, kentler yatırımları, nüfusu, turizmi kamu fonlarını/teşviklerini kendilerine çekerek, yetenekli ve eğitimli işgücü, yüksek çevresel standartlar ve yüksek yaşam standartları için rekabet etmektedirler (Döven, 2013: 192). Küreselleşme asıl etkisini kent kimlikleri, kentsel hizmet kalitesi, çevre değerleri ve kentsel altyapı üzerinde göstermektedir (Keleş, 2015: 75). Bu bağlamda rekabet gücünün kent düzeyinde ele alınmasında; "yaşam kalitesi" kavramından yararlanıldığı, yaşam kalitesini belirleyen faktörlerin ise istihdam düzeyi ve verimlilik (Albayrak ve Erkut, 2010: 138) şeklinde sıralandığ1 görülmektedir. Dolayısıyla rekabet gücünün, kentler açısından da ekonomik güç, olarak algılandığı anlaşılmaktadır. 
Tablo. 7 Dünya Genelindeki En Rekabetçi 20 Kent (2017 yılı)

\begin{tabular}{|c|l|c|c|c|c|}
\hline Sıra & \multicolumn{1}{|c|}{ Şehir } & Düzey & $\begin{array}{c}\text { Ekonomik } \\
\text { Rekabetçilik }\end{array}$ & Ülke & Kıtası \\
\hline $\mathbf{1}$ & New York & A+ & 1.000 & A.B.D. & Kuzey Amerika \\
\hline $\mathbf{2}$ & Los Angeles & A & 0.999 & A.B.D. & Kuzey Amerika \\
\hline $\mathbf{3}$ & Singapur & A & 0.971 & Singapur & Asya \\
\hline $\mathbf{4}$ & Londra & A & 0.958 & Birleşik Krallık & Avrupa \\
\hline $\mathbf{5}$ & San Francisco & A & 0.941 & A.B.D. & Kuzey Amerika \\
\hline $\mathbf{6}$ & Shenzhen (Şenzen) & B & 0.934 & Çin & Asya \\
\hline $\mathbf{7}$ & Tokyo & A- & 0.920 & Japonya & Asya \\
\hline $\mathbf{8}$ & San Jose & A & 0.916 & A.B.D. & Kuzey Amerika \\
\hline $\mathbf{9}$ & Münih & B+ & 0.905 & Almanya & Avrupa \\
\hline $\mathbf{1 0}$ & Dallas & A- & 0.903 & A.B.D. & Kuzey Amerika \\
\hline $\mathbf{1 1}$ & Houston & A- & 0.900 & A.B.D. & Kuzey Amerika \\
\hline $\mathbf{1 2}$ & Hong Kong & A & 0.887 & Çin & Asya \\
\hline $\mathbf{1 3}$ & Seul & A- & 0.848 & Kore & Asya \\
\hline $\mathbf{1 4}$ & Shanghai (Şanghay) & A- & 0.837 & Çin & Asya \\
\hline $\mathbf{1 5}$ & Guangzhou & B+ & 0.835 & Çin & Asya \\
\hline $\mathbf{1 6}$ & Miami & B+ & 0.816 & A.B.D. & KuzeyAmerika \\
\hline $\mathbf{1 7}$ & Chicago & A- & 0.815 & A.B.D. & KuzeyAmerika \\
\hline $\mathbf{1 8}$ & Boston & A- & 0.812 & A.B.D. & KuzeyAmerika \\
\hline $\mathbf{1 9}$ & Dublin & A- & 0.811 & İrlanda & Avrupa \\
\hline $\mathbf{2 0}$ & Pekin (Beijing) & A- & 0.810 & Çin & Asya \\
\hline
\end{tabular}

Kaynak: UN-HABITAT, 2017: 70.

UN-HABITAT tarafından, 2017 yılının en rekabetçi kentlerine ilişkin yapılan sıralamada, kentlerin ekonomik güçleri esas alınmış ve bu kapsamda bir değerlendirme yapılmıştır. Buna göre, rekabetçi kentlerin 9'unun Kuzey Amerika, 8'inin Asya, 3'ünün ise Avrupa Kıtası'nda yer aldığı görülmektedir. Kentlerin bölgesel dağılımına bakıldığında ise; ABD'den Kaliforniya eyaleti; Los Angeles, San Francisco ve San Jose kentleri ile öne çıkmaktadır. Rekabetçilikte, Kaliforniya'yı, Dallas ve Houston kentleri ile Teksas eyaleti, takip etmektedir. Ayrıca listede, New York (New York Kenti), Florida (Miami Kenti), Illinois (Chicago Kenti) ve Massachusetts (Boston Kenti) eyaletleri de yer almaktadır.

Asya Kıtası'nda ise, rekabetçi ülkelerin genel itibariyle Çin'de yer aldığı gözlemlenmektedir. Singapur, Japonya ve Kore, Çin'i takip eden ülkeler arasındadır. Bölgesel açıdan bir değerlendirme yapıldığında; Çin'in güneyinde yer alan Guangdong eyaleti (Şenzen ve Guangzhou Kentleri), ülkenin güney kıyısında yer alan ve özel bir yönetim biçimine sahip olan Hong Kong, ülkenin en büyük kenti olan Şangay ve başkent Pekin'in öne çıktığı görülmektedir. Asya Kıtası'ndaki diğer rekabetçi kentler ise; Singapur'un başkenti Singapur, Japonya'nın başkenti Tokyo ve Güney Kore'nin başkenti Seul'dür. Tablo.7'de belirtildiği üzere, rekabetçi dünya kentleri sıralamasında, Avrupa Kıtası'ndan ise 3 kent bulunmaktadır. Bu kentlerden ikisi; başkent statüsünde yer alan Londra (hem İngiltere hem Birleşik Krallık) ve Dublin (İrlanda)'dir. Almanya'nın Bavyera eyaletindeki bir kent olan Münih ise, başkent olmadığı halde rekabette öncü kentlerden biri olarak ön plana çıkmaktadır.

UN-HABITAT tarafından hazırlanan çalışmada, dünya genelinde, en rekabetçi 20 kentin yanı sıra, toplam 200 kentin de ekonomik açıdan rekabet güçleri incelenmiştir. Bu kentler arasında, Türkiye'den 0.7480 puan ile 33. sırada İstanbul ve 0.5241 puan ile 181. sırada Kocaeli'nin Gebze ilçesi bulunmaktadır (UN-HABITAT, 2017: 71-13).

\footnotetext{
${ }^{2}$ Hong Kong, özel statülü bir bölge olduğu için bazı kaynaklarda ayrı bir ülke, bazı kaynaklarda ise Çin’e bağlı özel bir idari bölge olarak geçmektedir. Çin Halk Cumhuriyeti Hong Kong SAR (Özel İdari Bölgesi): "Hong Kong, 1842 yılında Nanking Antlaşması'yla Çinlilerden İngilizlere geçmiştir. 1949'da Birleşik Krallık'ın Çin'i tanımasıyla ekonomik hayatı gelişen Hong Kong, II. Dünya Savaşı esnasında (24 Aralık 1941'de) Japonların eline geçmiștir. Hong Kong, 1945'te yeniden Britanyalılara verilmiş, yapılan anlaşma neticesinde 1 Temmuz 1997'de Çin'e geri verilmiştir. Bu gelișme ile birlikte, Hong Kong, Çin'e bağlı özerk bir bölge haline getirilmiştir” (https://tr.wikipedia.org/wiki/Hong_Kong). Ayrıntılı bilgi için bkz: Asuman Suner (1997) "Hong Kong: Sömürgecilik Tarihinde Bir Sayfa Kapanırken"; http://www.birikimdergisi.com/birikim-yazi/2815/hong-kong-somurgeciliktarihinde-bir-sayfa-kapanirken\#.W2HDF9Izbs1
} 
Tablo. 8 Rekabet Gücü En Düşük 10 Kent (2017 yılı)

\begin{tabular}{|l|l|c|c|c|c|}
\hline Sıra & \multicolumn{1}{|c|}{ Şehir } & Düzey & $\begin{array}{c}\text { Ekonomik } \\
\text { Rekabetçilik }\end{array}$ & Ülke & Kıtası \\
\hline $\mathbf{1 9 1}$ & Marsilya & C & 0.5179 & Fransa & Avrupa \\
\hline $\mathbf{1 9 2}$ & Nottingham & C- & 0.5168 & Birleşik Krallık & Avrupa \\
\hline $\mathbf{1 9 3}$ & Omaha & C+ & 0.5158 & A.B.D. & Kuzey Amerika \\
\hline $\mathbf{1 9 4}$ & Shaoxing & C- & 0.5157 & Çin & Asya \\
\hline $\mathbf{1 9 5}$ & Leicester & C & 0.5156 & Birleşik Krallık & Avrupa \\
\hline $\mathbf{1 9 6}$ & Daegu & C & 0.5155 & Güney Kore & Asya \\
\hline $\mathbf{1 9 7}$ & Montevideo & C & 0.5140 & Uruguay & Güney Amerika \\
\hline $\mathbf{1 9 8}$ & Dongying & C- & 0.5132 & Çin & Asya \\
\hline $\mathbf{1 9 9}$ & Taizhou (Js) & C- & 0.5128 & Çin & Asya \\
\hline $\mathbf{2 0 0}$ & Panama City & C & 0.5114 & Panama & Orta Amerika \\
\hline
\end{tabular}

Kaynak: UN-HABITAT, 2017: 75.

Tablo.8'de yer verilen rekabet gücü en düşük, 10 kent değerlendirildiğinde; kentlerin, $C$ (+,-) düzeyindeki kentlerden oluştuğu görülmektedir. Ayrıca bu 10 kentin; 3'ü Avrupa, 3'ü Amerika, 4'ü ise Asya Kıtası'nda yer almaktadır. Kentler incelendiğinde, Avrupa Kıtası'nda; Fransa'dan 1, Birleşik Krallık'tan ise 2 kentin son 200 kent arasında, yer aldığı görülmektedir. Amerika Kıtası'nda yer alan kentlerin, kıtanın kuzey-güney ve orta kesimlerine dağılmış olduğu anlaşılmaktadır. Buna göre, Nebraska eyaletinde bulunan Omaha; Uruguay'ın başkenti olan Montevideo ve Panama'nın başkenti olan Panama City, rekabet gücü en düşük kentler, arasında bulunmaktadır. Asya Kıtası açısından bir değerlendirme yapıldığında ise; Güney Kore'de bulunan Daegu kenti hariç, diğer 3 kent Çin sınırları içinde yer almaktadır. Rekabet gücü, en yüksek ve düşük kentler bir arada değerlendirildiğinde ise, aynı ülkenin aynı bölgelerinde yer alan kentlerde bile rekabet gücü, yani ekonomik güç noktasında, önemli uçurumlar yaşandığı dikkat çekmektedir. Bu durum bölgelerarası rekabetin yerini, kentler arası rekabete bıraktığının önemli bir kanıtını teşkil etmektedir.

\section{KENTLER ARASI REKABET VE TÜRKIYYE}

Çalışmanın ekseni itibariyle, güncel veriler eşliğinde dünya kentlerinin rekabetçilik seviyelerinin belirlenmesinin ardından, geliştirilen belirli endeksler çerçevesinde Türkiye'deki kentlerin konumlarının tartışılması gerekmektedir. Kent rekabetçiliği konusunda, Türkiye özelinde, kamu kurumları, akademisyenler, sivil toplum kuruluşları ve özel kuruluşlar tarafından gerçekleştirilen çeşitli çalışmalar bulunmaktadır. Ancak belirtmek gerekir ki, muhtemelen ülkenin temel gerçeklerinden birisi olan bölgelerarası kalkınma ve gelişmişlik noktasında dengesizlikler olduğu için, bu çalışmalarda genellikle kalkınma, gelişmişlik gibi kavramlar merkezde yer almaktadır (Döven, 2013: 198). Ayrıca bu çalışmalarda izlenen genel yol, belirli değişkenler esas alınarak toplanan verilerin karşılaştırmalı analizi şeklinde, ilerlemekte ve çalışmaların genelinde kent kavramından ziyade şehir veya daha geniş olan il ifadesinin kullanıldığı dikkat çekmektedir. Bu konuda gerçekleştirilen ilk çalışmalar, 1996 yılında DPT tarafından yapılan SEGE (İllerin ve Bölgelerin Sosyo-Ekonomik Gelişmişlik Sıralaması Araştırması) yapılan araştırmaların öncüsü olarak, nitelendirilmektedir. Çalışma, demografi, istihdam, eğitim, sağlık, sanayi, tarım, inşaat, altyapıya ilişkin göstergelerin yanı sıra mali göstergeler ile diğer refah göstergelerinden oluşmaktadır. İlleri gelişme durumlarına göre beş kademede ela alan çalışmaya göre; İstanbul, Ankara, İzmir, Kocaeli, Bursa illeri birinci kademede yer alırken, Tunceli, Adıyaman, Kars, Gümüşhane, Bayburt, Batman, Mardin, Van, Siirt, Iğdır, Hakkâri, Bitlis, Ardahan, Bingöl, Ağrı, Şırnak ve Muş son kademede yer almaktadır (Aktan, 2002: 4). Çalışmada, sosyal ve ekonomik göstergelere yansıyan mekânsal farklılaşmanın, ülke genelinde yaşanan yerleşme sorunu ile iç içe geçtiği ifade edilmekte; geri kalmış bölgelerdeki sorunların durgunluk, yatırım ve hizmet eksikliği olduğu, gelişmiş yerlerde ise hızlı nüfus artışına paralel bir biçimde işsizlik, altyap1 yetersizliği, kaçak yapılaşma, asayiş ve artan çevre sorunları olduğu belirtilmektedir (Dinçer, 1996; 9).

2002 yılında, Barca ve arkadaşları tarafından hazırlanan çalışma ise, Çorum, Denizli, Gaziantep, Kayseri ve Kahramanmaraş'ın belirli değişkenler üzerinden karşılaştırılması esasına dayanmaktadır. Buna göre iç ve dış olmak üzere, iki temel faktör ve bunlara bağlı alt faktörler geliştirilmektedir. Çalışmada, kentlerdeki hâkim sanayi kolu, sanayi yoğunluğu, kümelenme, politik iklim, stratejik konum, faktör koşulları ve talep koşulları gibi unsurların dış faktörler arasında sınıflandırıldığı görülmektedir. Kentlerin rekabet düzeyini ölçmede kullanılan iç faktörler ise, kaynaklar ve yetkinlikler, kültürel iklim, öğrenme bölgeleri, girişimcilik yeteneği şeklinde belirlenmektedir (Barca vd., 2002).

Alandaki bir diğer çalışma ise Aydemir (2002) tarafından yapılmıştır. Bu çalışmada bölgelerin görece rekabet edebilirliğinin ölçülmesinde; veri zarflama analizi yöntemi, kullanılarak Türkiye'deki illere yönelik 
bir verimlilik analizinin yapıldığı, dikkat çekmektedir. $\mathrm{Bu}$ analiz kapsamında, rekabet gücünün belirlenmesinde illerin hangi kaynakları ne derecede verimli kullandığı esas alınarak, iller bir sınıflandırmaya tabi tutulmuştur (Aydemir, 2002: 94; Döven, 2013: 199). Çalışmada veri eksiklikleri nedeniyle; Kırklareli, Uşak, Siirt ve Düzce hariç 77 ilin incelendiği vurgulanmaktadır. Rekabet gücünün belirlenmesinde; 8 girdi, 1 çıktı faktörünün esas alındığ 1 çalışmaya göre; rekabetçi yapı, nitelikli insan gücü, ulaştırma altyapısı ve yatırımları, esnaf, sanatkâr ve küçük sanayi yatırımları, tarım, imalat ve madencilik, enerji ve diğer hizmetler sektörlerinde gerçekleşen teşvik belgeli yatırımlar ile tarım ve imalat sektörlerinde hizmet veren KOBİ'lere verilen toplam yatırım ve işletme kredileri, girdi faktörü, olarak kabul edilmektedir. Çıktı ise, il bazında üretilen katma değerden oluşmaktadır (Aydemir, 2002: 102-103).

Türkiye'de kentlerin rekabet güçlerinin ölçülmesinde, günümüzdeki birçok çalışmanın temelinde yer alan bir diğer çalışmanın ise 2003 yılında DPT tarafından yayımlandığ 1 görülmektedir. Dinçer ve arkadaşları tarafından gerçekleştirilen (SEGE-2003) bu çalışma, mevcut idari yapı çerçevesinde 81 ili kapsamaktadır. (Dinçer vd., 2003: 20; Döven, 2013: 200). "Gelişmişliğin mümkün olduğu kadar çok boyutunu hesaba katabilmek için, değişken sayısının güvenilir ve tutarlı veri bulunabildiği ölçüde, geniş tutulmasına" özen gösterildiği çalışmada sosyal ve ekonomik olmak üzere, iki temel değişken grubunun belirlendiği görülmektedir. Buna göre, demografik değişkenler; istihdam, eğitim, sağlık, altyap1 ve diğer refah değişkenleri, sosyal değişkenler arasında sıralanmaktadır. Ekonomik değişkenler grubu ise, imalat sanayii, inşaat, tarım değişkenleri ile mali değiş̧enlerden oluşmaktadır.Temel bileşenler analizi, tekniğinin kullanıldığı çalışmada, kentlerin rekabet gücünü ölçmek için, belirtilen değişkenler kapsamında 58 gösterge yer almakta ve gelişmişlik endeksine göre kademeli il grupları belirlenmektedir (Dinçer vd., 2003).

Tablo. 9 Türkiye'de Kent Rekabetçiliği Alanında Yapılan Bazı Çalışmalar ${ }^{3}$

\begin{tabular}{|c|c|c|c|c|}
\hline Yıl & Kurum & Endeks Adı & $\begin{array}{l}\text { Alt Endeks } \\
\text { Sayısı }\end{array}$ & $\begin{array}{l}\text { Değişken } \\
\text { Sayısı }\end{array}$ \\
\hline 1996 & DPT & $\begin{array}{l}\text { İllerin ve Bölgelerin Sosyo-Ekonomik Gelişmişlik } \\
\text { Sıralaması Araştırması (SEGE) }\end{array}$ & 10 & 58 \\
\hline 2003 & DPT & $\begin{array}{l}\text { İllerin ve Bölgelerin Sosyo-Ekonomik Gelişmişlik } \\
\text { Sıralaması Araştırması (SEGE) }\end{array}$ & 10 & 58 \\
\hline 2007 & ALKİN/BULU/KAYA & İllerarası Rekabetçilik Endeksi & 4 & 36 \\
\hline 2008 & URAK & URAK-İlleraras1 Rekabetçilik Endeksi 2007-2008 & 4 & 36 \\
\hline 2008 & DPT/ Murat KARA & İller Bazında Rekabet Edebilirlik Kademelenmesi & 5 & 30 \\
\hline 2009 & URAK & URAK-İlleraras1 Rekabetçilik Endeksi 2008-2009 & 4 & 39 \\
\hline 2009 & EDAM & Türkiye İçin Bir Rekabet Endeksi & 6 & 52 \\
\hline 2010 & URAK & URAK-İlleraras1 Rekabetçilik Endeksi 2009-2010 & 4 & 42 \\
\hline 2010 & ALBAYRAK/ERKUT & Bölgesel Rekabet Gücü Endeksi & 5 & 32 \\
\hline 2011 & URAK & URAK-İllerarası Rekabetçilik Endeksi 2010-2011 & 4 & 40 \\
\hline 2011 & EGEV & İlleraras1 Rekabet Endeksi-2011 (Ege Bölgesi) & 21 & 56 \\
\hline 2011 & Boğaziçi Üniversitesi & Türkiye'nin Şehirleri Sürdürülebilirlik Araştırması & 3 & 63 \\
\hline 2011 & Mevlana Kalkınma Ajns & Konya Karaman İlçeleri Sosyal Gelişmişlik Endeksi & 3 & 17 \\
\hline 2012 & İstanbul Üniversitesi & 26 Bölge- 81 İl Küresel Rekabet Endeksi & 3 & 338 \\
\hline 2013 & $\begin{array}{l}\text { Prof..Dr. Ali Riza } \\
\text { KARACAN }\end{array}$ & $\begin{array}{l}\text { En Yaşanabilir Kentler -Sürdürülebilir Kalkınma } \\
\text { Endeksi (Çevre Ekonomisi ve Politika Kitabı) }\end{array}$ & - & - \\
\hline 2013 & T.C. Kalkınma Bakanlığı & $\begin{array}{l}\text { İllerin ve Bölgelerin Sosyo-Ekonomik Gelişmişlik } \\
\text { Sıralaması Araştırması (SEGE-2011) }\end{array}$ & 8 & 61 \\
\hline 2014 & İş Bankası & $\begin{array}{l}\text { İllerin Gelişmişlik Düzeyi Araştırması (İGE- } \\
\text { 2010/İGE-2012) }\end{array}$ & 2 & 49 \\
\hline 2014 & URAK & URAK-İlleraras1 Rekabetçilik Endeksi 2012-2013 & 4 & 61 \\
\hline 2014 & Kayseri Ticaret Odası & $\begin{array}{l}\text { Kayseri Rekabet Endeksi, 2013-2014 (Rekabet } \\
\text { Endeksi-81 İl) }\end{array}$ & 3 & 276 \\
\hline 2015 & TÜİK & İllerde Yaşam Endeksi (Well-Being Index) & 11 & 41 \\
\hline 2016 & URAK & URAK-İlleraras1 Rekabetçilik Endeksi 2013-2014 & 4 & 68 \\
\hline 2016 & EDAM\&TÜRKONFED & Türkiye İçin Rekabet Endeksi Raporu & 8 & 65 \\
\hline 2017 & İSTKA & İstanbul Rekabet Endeksi & 9 & 100 \\
\hline 2019 & URAK & URAK-İllerarası Rekabetçilik Endeksi 2018 & 4 & 85 \\
\hline
\end{tabular}

Kaynak: URAK, 2019: 16.

Türkiye'de kent rekabetçiliği alanında yürütülen çalışmaların özetlendiği Tablo.9 incelendiğinde; çalı̧̧maların bir kısmının yerel, bir kısmının bölgesel, bir kısmının ise genel mahiyette, olduğu görülmektedir.

\footnotetext{
${ }^{3}$ Türkiye'de kentler arası rekabetçilik kapsamında hazırlanan endeksleme çalışmalarının kentten daha geniş bir alanı kapsayacak şekilde ve genellikle il bazında ele alındığı belirlenmektedir. Bu nedenle Türkiye ile ilgili kısımlarda çalışmaların içeriğinde yer aldığı şekliyle il kavramının kullanılmasına özen gösterilmiştir.
} 
Dolayısıyla kentler arası rekabet konusunun, Türkiye'de ilgi kazandığı ve alandaki çalışmaların arttığı anlaşılmaktadır. Hatta 2009 yılında Bayındırlık ve İskân Bakanlığı (2011 yılında yapılan değişiklik ile Çevre ve Şehircilik Bakanlığı) bünyesinde oluşturulan Kentleşme Şûrası kapsamında, Bölgesel Eşitsizlik, Yerel Kalkınma ve Rekabet Edebilir Kentler Komisyonu'nun kurulduğu ve Komisyonun konuya ilişkin sorun alanlarını tespit edip, stratejiler geliştirdiği bilinmektedir. Ancak bütün çalışmaların her sene geliştirildiği ve güncellendiğini söylenememektedir. Bu kapsamda, çalışmaların tamamına burada yer vermek mümkün olmadığ 1 için, çalışmada Türkiye'deki mevcut kentlerin rekabet düzeylerinin, en güncel, kapsamlı ve nispeten sürekliliği bulunan çalışmalar esas alınarak değerlendirilmesi yapılmaktadır.

2013 yılında, Bölgesel Gelişme ve Yapısal Uyum Genel Müdürlüğ̈̈ tarafından hazırlanan (SEGE 2011) kapsamında, SEGE 2003'teki göstergelerin geliştirilip 61'e çıkarıldığı, demografi (5), istihdam (8), eğitim (6), sağl1k (5) ve mali (7) göstergelere ilaveten, rekabetçi ve yenilikçi kapasite (15), erişilebilirlik (6) ve yaşam kalitesi (9) alanlarından da değişkenler kullanıldığı görülmektedir (Kalkınma Bakanlığı, 2013: 22-23). Ülkedeki 81 ilin, hem il, hem de İstatistikî Bölge Birimleri Sınıflamasına göre, sıralamasının yapıldığı bu çalışmada illerin, gelişmişlik düzeylerine göre, altı kademeye ayrıldığı belirlenmektedir. Buna göre; birinci kademe gelişmiş 8 il, ikinci kademe gelişmiş 13 il, üçüncü kademe gelişmiş 12 il, dördüncü kademe gelişmiş 17 il, beşinci kademe gelişmiş 16 il ve altıncı kademe gelişmiş 15 il, bulunmaktadır (Kalkınma Bakanlığı, 2013).

Tablo. 10 Türkiye'nin En Gelişmiş İlleri (SEGE-2011)

\begin{tabular}{|c|c|c|c|}
\hline Sura & İl Kodu & İller & Endeks Değeri \\
\hline $\mathbf{1}$ & TR100 & İstanbul & 4,5154 \\
\hline $\mathbf{2}$ & TR510 & Ankara & 2,8384 \\
\hline $\mathbf{3}$ & TR310 & İzmir & 1,9715 \\
\hline $\mathbf{4}$ & TR421 & Kocaeli & 1,6592 \\
\hline $\mathbf{5}$ & TR611 & Antalya & 1,5026 \\
\hline $\mathbf{6}$ & TR411 & Bursa & 1,3740 \\
\hline $\mathbf{7}$ & TR412 & Eskişehir & 1,1671 \\
\hline $\mathbf{8}$ & TR323 & Muğla & 1,0493 \\
\hline $\mathbf{9}$ & TR211 & Tekirdağ & 0,9154 \\
\hline $\mathbf{1 0}$ & TR322 & Denizli & 0,9122 \\
\hline
\end{tabular}

Kaynak: Kalkınma Bakanlığı, 2013: 50.

Tablo.10'daki sıralama incelendiğinde; Türkiye'de sosyo-ekonomik açıdan en gelişmiş illerin sanayi, ekonomi, hizmet sektörü ve yaşam kalitesi gibi birçok faktör açısından ülkede en çok tercih edilen, aynı zamanda nüfusun da yoğun olarak yaşadığı kentler, olduğu dikkat çekmektedir. Tekirdağ ve Denizli hariç sıralamadaki diğer 8 il, birinci kademe gelişmiş iller arasında yer almaktadır. Ayrıca ilk 10 il arasına girmeyi başaran Muğla, Tekirdağ ve Denizli illerinin 12/11/2012 tarihli ve 6360 sayılı Kanun ile yeni büyükşehir yapılan iller arasında, yer aldığı görülmektedir.

Tablo. 11 Sosyo-Ekonomik Gelişmişlik Düzeyi En Düşük İller (SEGE-2011)

\begin{tabular}{|c|c|c|c|}
\hline Sıra & İl Kodu & İller & Endeks Değeri \\
\hline $\mathbf{7 2}$ & TRB13 & Bingöl & $-1,1920$ \\
\hline $\mathbf{7 3}$ & TRC21 & Şanlıurfa & $-1,2801$ \\
\hline $\mathbf{7 4}$ & TRC31 & Mardin & $-1,3591$ \\
\hline $\mathbf{7 5}$ & TRB21 & Van & $-1,3783$ \\
\hline $\mathbf{7 6}$ & TRB23 & Bitlis & $-1,4003$ \\
\hline $\mathbf{7 7}$ & TRC34 & Siirt & $-1,4166$ \\
\hline $\mathbf{7 8}$ & TRC33 & Şırnak & $-1,4605$ \\
\hline $\mathbf{7 9}$ & TRA21 & Ağr1 & $-1,6366$ \\
\hline $\mathbf{8 0}$ & TRB24 & Hakkâri & $-1,6961$ \\
\hline $\mathbf{8 1}$ & TRB22 & Muş & $-1,7329$ \\
\hline
\end{tabular}

Kaynak: Kalkınma Bakanlığı, 2013: 50.

Türkiye'nin gelişmişlik düzeyi en düşük, 10 ili incelendiğinde ise; illerin tamamının Doğu ve Güneydoğu Anadolu Bölgesi'nde bulunduğu görülmektedir. Tablo.10 ve Tablo.11'deki endeks değerleri karşılaştırıldığında; birinci sırada yer alan İstanbul ile son sırada yer alan Muş arasında yaklaşık 6,24'lük bir puan farkı bulunduğu anlaşılmaktadır. Ayrıca Tablo.11'deki illerin tamamının altıncı kademedeki iller arasında yer aldığı, 6360 sayılı Kanun ile büyükşehir olan, Şanlıurfa, Mardin, Van illerinin de, gelişmişlik düzeyi düşük son 10 il arasında bulunması dikkat çekmektedir. 


\section{Harita.1 Sosyo-Ekonomik Gelişmişlik Durumlarına Göre İller}

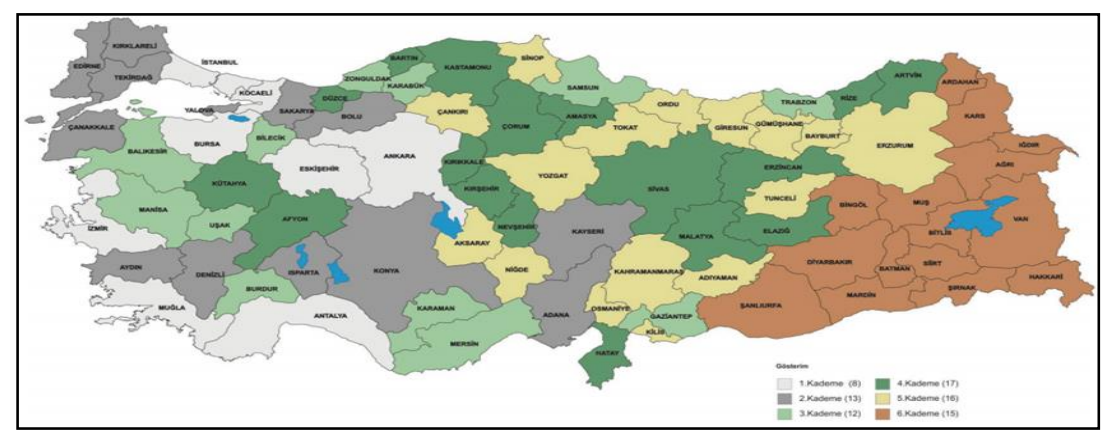

Kaynak: Kalkınma Bakanlı̆̆ı, 2013: 52.

Türkiye'nin sosyo-ekonomik gelişmişliğine ilişkin genel bir kanaat, Harita.1 aracılı̆̆ıyla elde edilebilmektedir. Bu doğrultuda bölgesel açıdan bir değerlendirme yapıldığında; ülkedeki gelişmişlik farklılıklarının yalnızca bölgesel farklılıklar ile açıklanamayacağı ortadadır. Dolayısıyla aynı bölgede yer almasına rağmen Ankara, Konya, Karaman, Niğde ve Nevşehir illerinin her birinin farklı gelişmişlik seviyesinde bulunması verilebilecek örneklerden birini teşkil etmektedir. Bu açıdan bakıldığında, ülkede yaşanan bölgelerarası eşitsizlik sorunun günümüzde kentler arasında da derinleştiği söylenebilecektir.

Türkiye'de rekabet gücünün kent düzeyinde tespitine yönelik hazırlanan bir diğer çalışma TÜRKONFED (Türk Girişim ve İş Dünyası Konfederasyonu) ve EDAM (Ekonomi ve Dış Politika Araştırma Merkezi) işbirliğinde hazırlanan; Türkiye İçin Bir Rekabet Endeksi, başlıklı çalışmadır. İlk olarak, 2009 yılında yayımlanan bu endeksleme çalışmasının, yeni endeks grupları oluşturularak ve güncellenerek 2016 yılında güncellendiği görülmektedir. Temel bileşenler analizi yöntemiyle gerçekleştirilen çalışmada, kentlerin rekabet güçlerinin, 8 alt endeks ve bunlara bağlı olarak geliştirilen 65 değişken esas alınmak suretiyle ölçüldügü belirlenmektedir.

Rekabet endeksi için kullanılan alt endeksler ve değişken sayıları incelendiğinde; verilerin makroekonomik istikrar endeksi (6), piyasa büyüklüğü endeksi (8), finansal derinlik endeksi (6), emek piyasası endeksi (7), insan sermayesi endeksi (8), yaratıcı sermaye endeksi (7), sosyal sermaye endeksi (14) ve fiziki altyapı endeksi (9) esas alınarak, toplandığı ifade edilmektedir (EDAM, 2016: 64).

\section{Tablo. 12 Rekabet Gücü En Yüksek 10 İl (EDAM)}

\begin{tabular}{|c|l|c|c|c|}
\hline Sura & İl & $\begin{array}{c}\text { Endeks Değeri } \\
(\mathbf{2 0 1 4})\end{array}$ & $\begin{array}{c}\text { Endeks Değeri } \\
(\mathbf{2 0 0 8})\end{array}$ & $\begin{array}{c}\text { İ Sıralaması } \\
(\mathbf{2 0 0 8} \text { yll) }\end{array}$ \\
\hline $\mathbf{1}$ & İstanbul & 100 & 100 & $(1)$ \\
\hline $\mathbf{2}$ & Ankara & 79 & 89 & $(2)$ \\
\hline $\mathbf{3}$ & İzmir & 57 & 61 & $(3)$ \\
\hline $\mathbf{4}$ & Antalya & 56 & 54 & $(5)$ \\
\hline $\mathbf{5}$ & Kocaeli & 55 & 59 & $(4)$ \\
\hline $\mathbf{6}$ & Muğla & 51 & 47 & $(6)$ \\
\hline $\mathbf{7}$ & Eskişehir & 48 & 53 & $(7)$ \\
\hline $\mathbf{8}$ & Bursa & 43 & 49 & $(11)$ \\
\hline $\mathbf{9}$ & Denizli & 43 & 43 & $(9)$ \\
\hline $\mathbf{1 0}$ & Tekirdă̆ & 41 & 44 & \\
\hline
\end{tabular}

Kaynak: EDAM, 2016: 11.

Rekabet edebilirliğin tespitinde, SEGE Araştırmalarına kıyasla, 4 değişken daha fazla kullanan bu çalışmada, ilk ve son 10 sırada yer alan iller değerlendirildiğinde; özellikle ilk 10 il açısından, aynı illerin ipi gögüslediği dikkat çekmektedir. Merkezin 2008 yılında gerçekleştirdiği endeksleme çalışması ile karşılaştırma yapıldığında, İstanbul'un geçen altı yıllık süre içerisinde 100 tam puanı korumayı başardığı anlaşılmaktadır. Ankara ve İzmir'in ise, puan kaybı yaşadığı izlenimi söz konusu olmakla birlikte, rekabet güçlerini korumayı başardıkları belirlenmiştir. Ayrıca Antalya, Denizli ve Muğla illerinin 2008 yılına göre, sıralamadaki konumlarını ve dolayısıyla rekabet edebilirliklerini yükselttikleri, görülmektedir. Kocaeli, Eskişehir, Bursa ve Tekirdağ illerinin önceki çalışmaya göre, birer sıra geriledikleri tespit edilmiştir. Dolayısıyla bu kentlerin rekabet güçlerinde nispeten bir düşüş olduğu söylenebilir.

Tablo. 13 Rekabet Gücü En Düşük 10 İl (EDAM) 


\begin{tabular}{|c|l|c|c|c|}
\hline Sıra & \multicolumn{1}{|c|}{ İ } & $\begin{array}{c}\text { Endeks Değeri } \\
(\mathbf{2 0 1 4})\end{array}$ & $\begin{array}{c}\text { Endeks Değeri } \\
(\mathbf{2 0 0 8})\end{array}$ & $\begin{array}{c}\text { İ Suralaması } \\
(\mathbf{2 0 0 8} \text { yll) }\end{array}$ \\
\hline $\mathbf{7 2}$ & Bitlis & 9 & 8 & $(75)$ \\
\hline $\mathbf{7 3}$ & Van & 9 & 10 & $(72)$ \\
\hline $\mathbf{7 4}$ & Batman & 8 & 10 & $(73)$ \\
\hline $\mathbf{7 5}$ & Mardin & 7 & 6 & $(77)$ \\
\hline $\mathbf{7 6}$ & Siirt & 7 & 8 & $(74)$ \\
\hline $\mathbf{7 7}$ & Hakkâri & 7 & 5 & $(79)$ \\
\hline $\mathbf{7 8}$ & Ağrı & 6 & 6 & $(78)$ \\
\hline $\mathbf{7 9}$ & Şanlıurfa & 6 & 7 & $(81)$ \\
\hline $\mathbf{8 0}$ & Muş & 3 & 3 & $(80)$ \\
\hline $\mathbf{8 1}$ & Şırnak & 2 & 5 & \\
\hline
\end{tabular}

Kaynak: EDAM, 2016: 11.

Türkiye'nin rekabet gücü en düşük, 10 ilini değerlendirdiğimizde de, SEGE 2011'deki illerle hemen hemen aynı illeri kapsadığı, görülmektedir. İstisnai olarak belirtmek gerekir ki, SEGE 2011'de Bingöl, sıralamadaki iller arasında yer alırken, Batman yer almamaktadır. Bu durumun, kullanılan endeks değişkenlerinin ve çalışmaların yapıldığı yılların farklılığı ve kentlerin gelişme durumları ile ilgili olduğu, düşünülmektedir. İllerin rekabet güçleri 2008 yılı ile kıyaslandığında ise; Bitlis, Mardin, Hakkâri ve Muş illerinin rekabet güçlerinin nispeten arttı̆̆ , Van ve Şırnak'ın 1, Siirt'in 2, Şanlıurfa'nın 3 sıra gerilediği, Ağrı'nın ise, mevcut yerini koruduğu görülmektedir.

Alana katkı sağlayan ve en güncel verileri içermesi bakımından önem taşıyan, bir diğer çalışma Uluslararası Rekabet Araştırmaları Kurumu (URAK) tarafından hazırlanan, İllerarası Rekabetçilik Endeksi'dir. İlk kez 2009 yılında yayınlanan çalışmanın, ilerleyen süreçte geliştirildiği görülmektedir. 81 ilin birbirleri karşısındaki durumuna ilişkin değerlendirme yapılmasına imkân veren endekste; beşeri sermaye (16), yenilikçilik (12), üretim ve ticaret (34) ile yaşanabilirlik (23) olmak üzere 4 alt endeks ve bu endekslere bağlı olarak geliştirilen 85 değişken bulunmaktadır. Bu değişkenlerin, kalkınmanın ayrıntılı kriterlerini gösterecek şekilde, geniş kapsamlı olarak belirlendiği anlaşılmaktadır. Söz konusu değişkenlerin Süper Ligde ili temsil eden futbol takımı varlığından, ilin hava kalitesi değerine kadar, ilde yüksek hızlı tren varlığından ile ait bilimsel yayın sayısına kadar, geniş bir yelpazeye yayıldığı belirlenmektedir (URAK, 2019: 18). Belirtilen değişkenlerin de dâhil edildiği, 85 gösterge doğrultusunda, illerin rekabet edebilirlikte sergilemiş oldukları performansa ilişkin, nispi bir yorum yapabilmek ise Tablo. 14 aracılığıyla mümkün görünmektedir.

Tablo. 14 Endeks Bazında Yıllara Göre İllerin Durumu (2012-2017

\begin{tabular}{|l|c|c|c|c|c|}
\hline \multicolumn{1}{|c|}{ İl } & 2012 & 2013 & 2014 & 2015 & $2016-$ \\
& -13 & -14 & -15 & -16 & 17 \\
\hline İstanbul & 1 & 1 & 1 & 1 & 1 \\
\hline Ankara & 2 & 2 & 2 & 2 & 2 \\
\hline İzmir & 3 & 3 & 3 & 3 & 3 \\
\hline Kocaeli & 4 & 4 & 4 & 4 & 4 \\
\hline Bursa & 5 & 5 & 5 & 5 & 5 \\
\hline Eskişehir & 6 & 6 & 6 & 6 & 6 \\
\hline Antalya & 7 & 7 & 9 & 7 & 7 \\
\hline Konya & 8 & 8 & 8 & 8 & 8 \\
\hline Yalova & 13 & 10 & 9 & 9 & 9 \\
\hline Sakarya & 12 & 9 & 10 & 10 & 10 \\
\hline Tekirdağ & 9 & 11 & 11 & 11 & 11 \\
\hline Trabzon & 10 & 12 & 12 & 14 & 12 \\
\hline Denizli & 17 & 18 & 19 & 12 & 13 \\
\hline Edirne & 11 & 13 & 13 & 15 & 14 \\
\hline Bolu & 23 & 20 & 17 & 19 & 15 \\
\hline Adana & 15 & 14 & 16 & 13 & 16 \\
\hline Kayseri & 14 & 15 & 15 & 16 & 17 \\
\hline Isparta & 16 & 17 & 14 & 17 & 18 \\
\hline Aydın & 27 & 26 & 26 & 18 & 19 \\
\hline Gaziantep & 21 & 19 & 20 & 20 & 20 \\
\hline Karabük & 19 & 16 & 18 & 26 & 21 \\
\hline Kurşehir & 24 & 22 & 21 & 21 & 22 \\
\hline Samsun & 18 & 24 & 24 & 24 & 23 \\
\hline Muğla & 29 & 23 & 27 & 25 & 24 \\
\hline Çanakkale & 20 & 21 & 23 & 22 & 25 \\
\hline Mersin & 22 & 32 & 22 & 23 & 26 \\
\hline Rize & 31 & 29 & 30 & 30 & 27 \\
\hline Zonguldak & 33 & 30 & 31 & 31 & 28 \\
\hline & & & & & \\
\hline
\end{tabular}




\begin{tabular}{|c|c|c|c|c|c|}
\hline Manisa & 26 & 25 & 25 & 27 & 29 \\
\hline Kütahya & 30 & 34 & 32 & 29 & 30 \\
\hline Kırklareli & 32 & 31 & 28 & 33 & 31 \\
\hline Balıkesir & 35 & 35 & 29 & 28 & 32 \\
\hline Tunceli & 28 & 27 & 35 & 41 & 33 \\
\hline Kırıkkale & 34 & 41 & 40 & 34 & 34 \\
\hline Bilecik & 37 & 33 & 33 & 32 & 35 \\
\hline Elazı̆̆ & 25 & 28 & 41 & 39 & 36 \\
\hline Düzce & 45 & 44 & 42 & 42 & 37 \\
\hline Erzurum & 39 & 42 & 45 & 43 & 38 \\
\hline Erzincan & 43 & 40 & 39 & 47 & 39 \\
\hline Burdur & 41 & 43 & 34 & 35 & 40 \\
\hline Malatya & 40 & 39 & 36 & 37 & 41 \\
\hline Artvin & 36 & 38 & 38 & 38 & 42 \\
\hline Amasya & 50 & 45 & 43 & 45 & 43 \\
\hline Uşak & 52 & 49 & 49 & 46 & 44 \\
\hline Sivas & 38 & 36 & 44 & 36 & 45 \\
\hline Hatay & 42 & 46 & 48 & 48 & 46 \\
\hline Nevşehir & 48 & 37 & 37 & 40 & 47 \\
\hline Giresun & 44 & 50 & 54 & 51 & 48 \\
\hline Çankırı & 46 & 48 & 46 & 50 & 49 \\
\hline Afyonkarahisar & 57 & 54 & 47 & 44 & 50 \\
\hline Çorum & 55 & 53 & 55 & 53 & 51 \\
\hline Karaman & 49 & 47 & 50 & 49 & 52 \\
\hline Kahramanmaraş & 51 & 51 & 52 & 52 & 53 \\
\hline Yozgat & 58 & 63 & 63 & 58 & 54 \\
\hline Niğde & 54 & 57 & 59 & 55 & 55 \\
\hline Sinop & 59 & 58 & 62 & 59 & 56 \\
\hline Bartın & 60 & 62 & 53 & 56 & 57 \\
\hline Kastamonu & 47 & 52 & 57 & 63 & 58 \\
\hline Kilis & 64 & 56 & 51 & 54 & 59 \\
\hline Osmaniye & 61 & 55 & 58 & 61 & 60 \\
\hline Tokat & 63 & 61 & 61 & 62 & 61 \\
\hline Ordu & 53 & 60 & 56 & 60 & 62 \\
\hline Gümüşhane & 56 & 65 & 60 & 64 & 63 \\
\hline Ardahan & 71 & 69 & 66 & 69 & 64 \\
\hline Bayburt & 62 & 59 & 65 & 57 & 65 \\
\hline Adiyaman & 67 & 66 & 64 & 66 & 66 \\
\hline Aksaray & 66 & 67 & 68 & 65 & 67 \\
\hline Bingöl & 68 & 68 & 69 & 70 & 68 \\
\hline Diyarbakır & 65 & 64 & 67 & 67 & 69 \\
\hline Kars & 74 & 70 & 71 & 68 & 70 \\
\hline Siirt & 69 & 71 & 70 & 72 & 71 \\
\hline Bitlis & 70 & 75 & 74 & 73 & 72 \\
\hline Mardin & 73 & 73 & 73 & 77 & 73 \\
\hline Van & 75 & 74 & 78 & 74 & 74 \\
\hline Batman & 78 & 80 & 77 & 75 & 75 \\
\hline Şanlıurfa & 72 & 72 & 72 & 71 & 76 \\
\hline Iğdır & 77 & 78 & 75 & 76 & 77 \\
\hline Muş & 76 & 77 & 79 & 78 & 78 \\
\hline Şırnak & 79 & 76 & 80 & 79 & 79 \\
\hline Hakkâri & 80 & 79 & 76 & 80 & 80 \\
\hline Ağrn & 81 & 81 & 81 & 81 & 81 \\
\hline
\end{tabular}

Kaynak: URAK, 2019: 35

Tablo.14'te yer alan veriler, y1llar itibariyle geliştirilen endeksler kapsamında Türkiye'deki illerin rekabet güçleri hakkında ve 5 yıllık süre içerisinde sergilemiş oldukları performansa ilişkin, bir değerlendirme yapılmasına imkân tanımaktadır. Bu bağlamda, istisnai birkaç il haricinde diğer iller için değişken bir tablo yaşandığını, belirtmek gerekmektedir. Tıpkı SEGE ve EDAM araştırmasında olduğu gibi, bu çalışmada da rekabet gücü en yüksek üç ilin sırasıyla İstanbul, Ankara ve İzmir'den oluştuğu tespit edilmektedir. Ancak burada belirtmek gerekir ki; kurum tarafindan 2016 y1lında ve 2013-2014 verileri esas alınarak yayınlanan rapordaki genel endeks sıralamaları ile 2019 yılında 2016-2017 verileri esas alınarak yayınlanan genel endeks sıralamalarında, birtakım farklılıklar dikkat çekmektedir. Söz konusu farklılık yılların değişmesinden değil, aynı yıllara ait illerin sıralamasının değişmesinden kaynaklanmaktadır. Bu nedenle, 2019 raporunda yer alan sıralamalar üzerinden değerlendirme yapılmış olup, belirli noktalarda 2016 raporuna atıfta bulunmak, uygun görülmüştür. Gerek rekabet gücü en yüksek, gerekse de en düşük kentler açısından genel bir değerlendirme yapılacak olduğunda, karşımıza şu durumlar çıkmaktadır: 
Rekabette öncü beş kentin, yıllardır mevcut konumlarını korudukları görülmektedir. Ancak İstanbul, Ankara ve Kocaeli ilk endeks çalışmasının yapıldığı 2009-2010 döneminden itibaren, sıralamadaki yerlerini korumakta olup, İzmir ve Bursa'nın sadece 2010-2011 döneminde birer sıra değişiklik yaşadığ anlaşılmaktadır (URAK, 2016: 33). Rekabet gücü en yüksek ilk 10 il, açısından değerlendirme yapılacak olduğunda, bu illerin yoğunlukla büyükşehir belediyesi kapsamında, yer aldığı anlaşılmaktadır. Sıralamada en çok dikkati ise, 1995 y1lında il olan ve henüz büyükşehir statüsünde bulunmayan, Yalova'nın konumu çekmektedir. Endekslemenin ilk kez yapıldığ 1 , 2009-2010 döneminde 27. sırada yer alan Yalova (URAK, 2016: 33), 2016-2017 döneminde yani yaklaşık 7 yıllık süreçte, 9. sıraya yükselerek Türkiye'nin en rekabetçi illeri arasında yer almayı başarmış görünmektedir.

Tablo. 15 2016-2017’nin En Rekabetçi İlleri

\begin{tabular}{|c|l|c|}
\hline Sıra & İller & $\begin{array}{c}\text { 2016-2017 Genel } \\
\text { Endeks Değeri }\end{array}$ \\
\hline 1 & İstanbul & 69,13 \\
\hline 2 & Ankara & 46,04 \\
\hline 3 & İzmir & 33,80 \\
\hline 4 & Kocaeli & 28,39 \\
\hline 5 & Bursa & 25,49 \\
\hline 6 & Eskişehir & 22,63 \\
\hline 7 & Antalya & 22,53 \\
\hline 8 & Konya & 21,25 \\
\hline 9 & Yalova & 19,55 \\
\hline 10 & Sakarya & 19,22 \\
\hline
\end{tabular}

Kaynak: URAK, 2019: 30

Kurumun belirlediği, 4 alt endeks ve 85 gösterge kapsamında hesaplanan puanlara göre, Türkiye'nin en rekabetçi illerinin durumu Tablo.15'te görülmektedir. Buna göre; ilk iki sıradaki iller arasında bile 23,09'luk bir fark olduğu belirlenmektedir, dolayısıyla bu farkın sonlara doğru oldukça açılması kaçınılmaz görülmektedir.

Rekabet gücü en düşük iller incelendiğinde ise, karşımıza daha değişken bir tablo çıkmaktadır. Öncelikle Tablo. 14 incelendiğinde, son 10 il arasında 6360 sayılı Kanun ile büyükşehir olan Mardin, Van ve Şanlıurfa göze çarpmaktadır. Ancak yıllar itibariyle, Ağrı hariç bu 3 il başta olmak üzere, diğer 7 ilin de çok durağan bir seyir izlemediği anlaşılmaktadır. Bunlar içerisinde; Mardin'in, Van'ın, Şırnak'ın ve Hakkâri'nin nispeten istikrarlı olduğu, söylenebilecektir. Iğdır'ın ise, 2014-2015 dönemi haricinde her dönem gerileme eğiliminde olduğu, belirlenmektedir. Kurum tarafından, 2016 yılında yayınlanan rapordaki verileri de dâhil edecek şekilde bir değerlendirme yapılacak olursa; endekslemenin yapıldığı ilk dönem olan 2009-2010 döneminde Şanlıurfa'nın 70. sırada yer alırken 2016-2017 döneminde 76. siraya gerilediği belirlenmektedir. Ayrıca 7 yıllık dönem içerisinde, son 10 ilin sıralamadaki konumlarının değişimi kısaca özetlenecek olduğunda; Van'ın 75. sıradan 74. sıraya, Bitlis'in 74. sıradan 72. sıraya, Hakkâri'nin 81. sıradan 80. sıraya, Şırnak'in 80. sıradan 79. sıraya yükseldiği tespit edilmektedir. Burada en çok dikkat çeken, 7 yıllık dönemde 78. sıradan, 71'e yükselerek 7 sıra yukarıya konumlanan Siirt ve 79. siradan 73. siraya konumlanan Mardin olmaktadır (URAK, 2016: 33; URAK, 2019: 35).

\section{Tablo. 16 2016-2017 Döneminin Rekabet Gücü En Düşük İlleri}

\begin{tabular}{|c|l|c|}
\hline Sıra & İller & $\begin{array}{c}\text { 2016-2017 Genel } \\
\text { Endeks Değeri }\end{array}$ \\
\hline 72 & Bitlis & 8,72 \\
\hline 73 & Mardin & 8,13 \\
\hline 74 & Van & 7,96 \\
\hline 75 & Batman & 7,77 \\
\hline 76 & Şanlıurfa & 7,74 \\
\hline 77 & Iğdır & 6,97 \\
\hline 78 & Muş & 6,89 \\
\hline 79 & Şırnak & 6,59 \\
\hline 80 & Hakkâri & 6,01 \\
\hline 81 & Ağrı & 5,35 \\
\hline
\end{tabular}

Kaynak: URAK, 2019: 30.

Son 10 ilin puanları incelendiğinde ise; daha önce ifade edilen rekabet edebilirlik güçleri arasındaki farkın derinleştiği tespit edilmektedir. Buna göre, ülkenin en rekabetçi ili olan İstanbul ile rekabet gücü en düşük ili 
olan Ağrı arasında, yaklaşık 64 puanlık bir fark, olduğu gözlemlenmektedir. Bu durum ülkedeki gelişmişlik farkının da âdeta göstergesi niteliğini taşımaktadır.

Yine Tablo.14 doğrultusunda genel bir değerlendirme yapılacak olduğunda; 5 yıllık dönem içerisinde birçok ilin olumlu veya olumsuz anlamda dinamik bir yapıya sahip olduğu belirlenmektedir. Bu çerçevede, 5 sıra ve üstü değişiklik yaşayan illerden bahsetmek yeterli görülmektedir. Buna uygun olacak biçimde inceleme yapıldığında; Bolu, Aydın, Düzce ve Uşak'ın rekabetçilikte 8 sıra birden ilerleyen iller olarak karşımıza çıktığı, bu illeri 7 sıra ilerleyen Amasya ve Afyonkarahisar'ın takip ettiği belirlenmektedir. Muğla, Zonguldak ve Kilis ise 2012-2013 döneminden bu yana 5'er sira ilerleyen iller, olarak değerlendirilmektedir. Dolayısıyla bu illerin rekabet güçlerinin yıllar itibariyle önemli artış gösterdiğini, söylemek mümkün olabilmektedir. Sıralamadaki konumlarını olumsuz yönde değiştiren iller incelendiğinde ise; en önemli düşüşün 11 sıra birden gerileyen Kastamonu ve Elazığ'da yaşandığı tespit edilmektedir. Bu illeri; 9 sıra gerileyen Ordu ile 7 sıra birden gerileyen Gümüşhane, Sivas, Ardahan illeri takip etmektedir. Artvin'in 6, Çanakkale, Samsun ve Tunceli'nin ise 5 yıllık dönemde 5'er sıra gerilediği belirlenmektedir.

URAK tarafından gerçekleştirilen ilk endeksleme çalışmasının yapıldığı, 2009-2010 döneminden itibaren bazı illerin sırasının sabit kaldığı, bazı illerin konumunun birkaç sıra değiştiği, bazı illerde ise önemli değişiklikler yaşandığ görülmektedir. Buna göre; 81 il içerisinde, 2009-2017 arasındaki dönem içerisinde, rekabet gücü sıralamasında en büyük değişikliğin 35 sıra ilerleyerek 57. sıradan 22. sıraya yükselen Kırşehir'de yaşandığı, Tunceli'nin 28 sıra yükselerek, 61. sıradan 33. sıraya yerleştiği belirlenmektedir. Bu illeri 25 sıra yükselen Kırıkkale, 21 sıra yükselen Karabük ve 18 sıra yükselerek, ilk 10'a girmeyi başaran Yalova, izlemektedir (URAK, 2016: 33; URAK, 2019: 35).

Sıralamadaki yerlerini, gerileme yönünde, değiştiren iller incelendiğinde ise; en önemli değişikliklerin 2009 yılında 37. sırada iken, 2017'de 63. sıraya yerleşen yani 26 sıra birden gerileyen Gümüşhane ile başladığ1 görülmektedir. Bu ili, 7'den 29. sıraya yerleşerek 22 sıra gerileyen Manisa, 51'den 31. sıraya yerleşen Çorum, 16 sira gerileyerek 52'den 36. siraya yerleşen Karaman ile 15 sira gerileyerek 62'den 47. siraya yerleşen Ordu izlemektedir. Ayrıca Mersin ve Düzce'nin de 13'er sira birden gerilediği belirlenmektedir (URAK, 2016: 33; URAK, 2019: 35). En stabil illerin ise, İstanbul, Ankara, İzmir, Bursa, Kocaeli gibi zirvede yer alan illerden oluştuğu görülmektedir.

Büyükşehirler açısından bir değerlendirme yapılacak olduğunda ise; Türkiye'deki en rekabetçi 10 ilin neredeyse tamamının büyükşehirlerden oluştuğu belirlenmektedir. Ancak Şanlıurfa, Van, Mardin gibi istisnai olarak listenin sonlarında ya da Hatay, Erzurum gibi listenin ortasında yer alan büyükşehirlerin de olduğu, belirlenmektedir. Ancak genel itibariyle büyükşehirlerin rekabet güçlerinin yüksek olduğu görülmektedir. Türkiye'nin büyükşsehir belediyelerinin rekabet gücünün artmasında ise, insan sermayesinin önemli bir rol oynadığ1 ve özellikle en büyük üç ilde olmak üzere daha yenilikçi ve özgün mal ve hizmetlerin üretilmesini sağladığı (Dünya Bankası ve TEPAV, 2015: 5) düşünülmektedir. Ancak belirtmek gerekir ki, belirlenen değişkenler kapsamında Antalya, Adana, Manisa, Mersin ve Samsun'un yıllar itibariyle rekabet güçlerinde bir azalma yaşandığı dikkat çeken bir başka noktadır.

\section{SONUÇ ve DEĞERLENDİRME}

Ekonomi, siyaset, spor gibi her alanda mevcut ilişkileri etkileyen rekabet kavramının, kişi ve kurumları amaçlarına ulaştırmak ve mevcut konumlarından daha ileriye taşımada, iç ve dış çevrede ilişkileri etkileme özelliği vardır. Bu kapsamda rekabet kavramının önemi her geçen gün artmaktadır. Özellikle sermaye hareketlerindeki artış, küresel pazarlarda söz sahibi olabilmek gibi uluslararası gelişmelerin yaşandığı günümüz toplumunda, sadece kişi ve kurumların değil, ülkelerin, bölgelerin, kentlerin ve bunlara bağl1 yönetimlerin de rekabet içerisinde olduğu bilinmektedir. Bu rekabet halini bazı değişkenleri üzerinden, somut bir duruma dönüştürmek amacıyla birtakım endeksleme çalışmalarının yapıldığı görülmektedir. Farklı değişkenler esas alınarak, çeşitli kişi veya kuruluşlar tarafından yürütülen bu çalışmaların rekabet gücünün belirlenmesinde beşeri sermaye, ekonomik gidişat, ürün ve hizmet kalitesi ve çeşitliliği başta olmak üzere çok sayıda unsuru göz önünde bulundurduğu söylenebilir. Söz konusu bu çalışmaların, farklı kapsamlarda hazırlandığını ve nadir çalışmaların güncelliğini koruyabildiğini de belirtmek gerekmektedir.

Geçerliliği bulunan çalışmalardan biri olan Küresel Rekabetçilik Raporu, WEF tarafından yıllık olarak yayınlanmaktadır. Ülkelerin kurumsal yapısından mali piyasanın etkinliğine, altyapı yatırımlarından sağlık ve eğitime kadar, çeşitli göstergeler etrafında şekillenen bu çalışmada yıllık olarak revizyona gidilmektedir. Dolayısıyla incelenen ülke sayısı ve endekslemede kullanılan bileşenlerin farklılık göstermesi, gündeme gelebilmektedir. Yeni metodoloji kullanılarak oluşturulan en güncel rapora göre; 2018 yılının en rekabetçi ülkesi 85.6 puan ile geçen yılın ikincisi olan ABD, rekabet gücü en düşük ülke ise 35.5 puanla Çad olarak tespit edilmektedir. 140 ülkenin dâhil edildiği raporda Türkiye ise, sahip olduğu 61.6 puan ile 61 . sırada yerini 
almaktadır. Raporun yayınlandığı ilk dönem olan 2012-2013 döneminden itibaren, ülkenin listedeki konumu incelendiğinde ise; 2017-2018 dönemi hariç, diğer tüm dönemlerde önceki yıllara göre, gerileme yaşandığ1 tespit edilmektedir. Alt göstergeler bazında bir değerlendirme yapılacak olursa; Türkiye'nin pazar büyüklüğü noktasında 13. sırada yer almasına karşın, makroekonomik istikrar konusunda ise 116. sırada konumlandığı görülmektedir. Uluslararası Yönetim Geliştirme Merkezi (IMD) tarafından hazırlanan ve 63 ülkenin ele alındığı Dünya Rekabetçilik Yıllığı’na göre ise; 2018 yılında rekabet gücü en yüksek ülke yine ABD olurken, en düşük ülke Venezüella'dır. Türkiye ise, bu raporda 46. sırada yer almaktadır.

Rekabet gücünün sadece firma, bölge ve ülke bazında değerlendirilmesinin yetersiz kaldığı günümüzde, kentlerin rekabet edebilirliği daha önemli bir faktör olarak ön plana çıkmaktadır. Özellikle küreselleşmenin beraberinde yerelleşmeyi getirmesine, yerel değerlerin ve potansiyellerin önem kazanmasına bağlı olarak, kentlerin gittikçe değerlendiği bilinmektedir. Bu açıdan bakıldığında, ülkeler için geliştirilen rekabet gücü araştırmalarının, kent özelinde de hayata geçirildiği görülmektedir. Dolayısıyla kent rekabetçiliği konusunda da yapılan çalışmalar hızla artmaktadır. Burada belirtmek gerekir ki, kentlerin rekabet edebilir olmasındaki temel ölçüt, ekonomik güç, yatırımlar, kentteki bireylerin yaşam kaliteleri gibi kriterlere göre, belirlenmektedir. Dolayısıyla çalışmalarda; hem ekonomik büyüme hem de kalkınma ölçütleri, esas alınmaktadır. Bu çalışmalardan en güncel ve kapsamlılarından biri olan ve UN-HABITAT tarafından hazırlanan çalışmaya göre; 2017 yılında dünyanın en rekabetçi kenti New York iken, rekabet gücü en düşük olan kent Panama City olmuştur. Türkiye'nin en rekabetçi kenti olan İstanbul ise, listedeki 200 kent arasında 33. sirada yer almaktadır.

Dünyadaki gelişme ve değişimlerin hızını yakalamaya çalışan Türkiye'de de, kentler arası rekabet popülaritesi artan bir konu olduğu için, kamu sektörü, özel sektör, STK'lar ve akademisyenlerin bu alanda birtakım çalışmalara imza attığı görülmektedir. Ancak belirtmek gerekir ki, ülkede yapılan bu çalışmaların sürekliliği noktasında, birtakım aksaklıklar yaşandığı, bazı çalışmaların güncellenmediği, güncellenip sürekliliği sağlanmaya çalışılanların ise, verilerin geç yayınlanmasından dolayı mevcut hali, net yansıtamadığ görülmektedir. Dolayısıyla bu çalışmada yapılan değerlendirmeler, söz konusu kısıtlllık içerisinde gerçekleştirilmektedir. Ayrıca çalışmalarda kentten ziyade şehir veya il terimlerinin kullanıldığı, çünkü konuya daha geniş bir perspektiften bakıldığı, belirlenmektedir. Bu kapsamda Kalkınma Bakanlığı (SEGE 2011), EDAM ve URAK tarafından yapılan çalışmalarda, Türkiye'deki en rekabetçi kentlerin sırasıyla; İstanbul, Ankara ve İzmir'den oluştuğu görülmektedir. Rekabet gücü düşük kentler ise, çalışmalara göre farklılık göstermekle birlikte genellikle; Şırnak, Muş, Siirt, Şanlıurfa gibi Doğu ve Güneydoğu Anadolu Bölgesi’ne ait kentlerden oluşmaktadır. Bu noktada tüm çalışmalar incelendiğinde ve özellikle Tablo.14'teki beş yılı içeren veriler esas alındığında; ülkedeki mevcut bölgelerarası eşitsizlik sorunun kentlere yayıldığı ve aynı bölge içerisinde yer almasına rağmen bazı kentlerin rekabet gücünün çok yüksek, bazılarının ise oldukça düşük olduğu dikkat çekmektedir. Ancak Doğu ve Güneydoğu Anadolu Bölgeleri'ndeki illerin, ülkenin diğer illerine göre daha dezavantajlı durumda olduğu yadsınamaz bir gerçeklik olarak, karşımıza çıkmaktadır. Ayrıca büyükşsehir belediyesi olan yerlerin, rekabet edebilirlik kapasitelerinin daha yüksek olduğu, bu durumun ise kentlere yapılan yatırımların artması, istihdam edilen bireylerin niteliklerinde iyileşmeler yaşanması, eğitim düzeyinin daha yüksek olması, hizmet sektörünün daha yüksek standartlarda bulunması gibi birçok nedenle açıklanabilmektedir. Ancak bu durumun tüm büyükşehirler için geçerli olmadığını belirtmek gerekir. Örneğin, yeni büyükş̧ehir olan Tekirdağ rekabet gücü en yüksek yerler arasında sayılırken, 1993 yılında büyükşehir olan Erzurum ve Diyarbakır ortalamanın altında, bir seyir izlemekte, yeni büyükşehir olan Şanlıurfa, Van ve Mardin ise rekabet gücü en düşük kentler arasında yer almaktadır.

Bölgesel açıdan bir değerlendirme yapılacak olduğunda ise; aynı bölgede yer alan, birbirine yakın iki büyükşehirden, Samsun'un 23., Ordu'nun 62. sırada yer alması dikkat çekmektedir. İl belediyesi düzeyinde bulunan Kırşehir'in 22., Niğde'nin 55. sırada bulunması, Erzincan'ın 39., Ağrı'nın 81. sırada yer almas1 ve Manisa'nın 29. sırada yer alırken Afyonkarahisar'ın 50. sırada yer alması gibi birçok örnek ise kentler arasındaki eşitsizliğin derinleştiğinin bir göstergesi olmaktadır. Burada dikkat çeken nokta, merkezde belli bir kalkınma ivmesi yakalayan ilin bu kalkınmayı çevresindeki illere yansıtamaması ve sonucunda metropoliten bölgeleşmeyi ${ }^{4}$ oluşturamaması hususudur. Kentler arası eşitsizlik, bölgesel kalkınma farklılıklarını ortaya çıkarmaktadır. Bununla birlikte belli bir kalkınma ivmesi yakalamış kentlerin, nüfusu göçle sürekli artış gösterirken ilerleyen dönemlerde bu kentlerde büyük kente ilişkin sorunlar yaşanması muhtemeldir. Bir diğer ortaya çıkması muhtemel sorun ise, sürekli göç veren kentlerin az gelişmiş̧lik kısır döngüsü içine

\footnotetext{
${ }^{4}$ Metropoliten bölgeleşme, şehirleşme oluşumunun ileri ve özel bir hali olarak nitelendirilmektedir. Merkezdeki kent içine aldığı çeşitli büyüklüklerdeki ve uzaklıklardaki yerleşmelere çeşitli fonksiyonlar; sanayi, tarım, toptancılık vs. yerleştirirken, merkezde de kendine has başka fonksiyonlar, başka nitelikte işgücü yerleştirmektedir (Bal, 2015: 101).
} 
hapsolmalarıdır. Sonuç olarak her iki oluşumun da toplumsal maliyetleri oldukça yüksek seviyelerde olması kaçınılmaz görülmektedir. 


\section{KAYNAKÇA}

Acet, Hakan, Güvenek, Burcu ve Soydal, Haldun (2014). "Güvenirlik İhtiyacı ve Devletin Regülasyonu”. Selçuk Üniversitesi Sosyal Bilimler Meslek Yüksekokulu Dergisi 9(1-2), 501-520.

Aktan, Coşkun Can (Ed.), (2002). Yoksullukla Mücadele Stratejileri, Ankara: Hak-İş Konfederasyonu Yayını, 2002; http://www.canaktan.org/ekonomi/yoksulluk/ucuncu-bol/dpt-illerin.pdf, erişim tarihi 10.08.2018.

Albayrak, Ayşe Nur ve Erkut, Gülden (2010). Türkiye'de Bölgesel Rekabet Gücü Analizi, MEGARON 2010, 5 (3):137148; http://www.journalagent.com/megaron/pdfs/MEGARON_5_3_137_148.pdf, erişim tarihi 31.01.2019.

Ataç, Osman Ata (2017). "Geçim Ekonomisi Teşvikleri: Rekabet Gücü” 29 Kasım 2017; https://www.dunya.com/koseyazisi/gecim-ekonomisi-tesvikleri-rekabet-gucu/392449, erişim tarihi 30.01.2019.

Aydemir, Zeynep Canan (2002). "Bölgesel Rekabet Edebilirlik Kapsamında İllerin Kaynak Kullanım Görece Verimlilikleri: Veri Zarflama Analizi Uygulaması", (DPT Uzmanlık Tezi), Ankara; http://www.sbb.gov.tr/wpcontent/uploads/2018/11/Bolgesel_Rekabet_Edebilirlik_Kapsaminda_Illerin_Kaynak_Kullan\%C4\%B1m_Gorec e_Verimlilikleri_Veri_Zarflama_Analizi_Uygulamasi.pdf, erişim tarihi 08.08.2018.

Bal, Hüseyin (2015). Kent Sosyolojisi, Bursa: Sentez Yayın ve Dağıtım.

Barca, Mehmet, Coşkun, Recai ve Altunışık, Remzi (2002). "Explaining Performance Differences Among Turkish Cities: A Tale Of Five Cities"; https://www.researchgate.net/publication/267238441_EXPLAINING_PERFORMANCE_DIFFERENCES_AM ONG_TURKISH_CITIES_A_TALE_OF_FIVE_CITIES, erişim tarihi 08.08.2018.

Birleşmiş Milletler İnsan Yerleşimleri Programı- (UN-HABITAT) (2018). The Global Urban Competitiveness Report 2017-2018 (Shortversion); https://unhabitat.org/wp-content/uploads/2017/11/GUCR2017-2018-ShortVersion.pdf, erişim tarihi 23.07.2018

Çivi, Emin, Erol, İbrahim, İnanlı Turgay, Erol Demiray Ece, (2008). "Uluslararası Rekabet Gücüne Farklı Bakışlar", Ekonomik ve Sosyal Araştırmalar Dergisi, Bahar 2008, Cilt:4, Y11:4, Sayı:1, 4:1-22; http://dergipark.gov.tr/download/article-file/69120, erişim tarihi 15.07.2018.

Dilek, Pelin Yenigün (2016). Türkiye İçin Bir Rekabet Endeksi, TÜRKONFED ve EDAM, İstanbul,http://www.turkonfed.org/Files/ContentFile/turkiye-icin-bir-rekabet-endeksi-raporu.pdf, erişim tarihi 09.08.2018

Dinçer, Bülent (1996). İllerin Sosyo-Ekonomik Gelişmişlik Siralaması Araştırması, http:///C:/Users/Home/Downloads/1.pdf, erişim tarihi 13.05.2019.

Dinçer, Bülent, Özaslan, Metin, Kavasoğlu, Taner (2003). “illlerin ve Bölgelerin Sosyo-Ekonomik Gelişmişlik Sıralaması Araştırması”, Bölgesel Gelişme ve Yapısal Uyum Genel Müdürlüğü, Yayın No: DPT: 2671. Ankara, Mayıs, 2003; http://www.kalkinma.gov.tr/Lists/Yaynlar/Attachments/341/2003-05.pdf, erişim tarihi 08.08.2018.

Dinler, Zeynel (2014). Bölgesel İktisat, Bursa: Ekin Basım Yayın.

Döven, Musa Said, (2013). “Şehir Rekabetçiliğinin Ölçümü: Literatür İncelemesi”, Sosyal Bilimler Araştırmaları Dergisi. I, 189-213.

Dünya Bankası ve TEPAV (2015). Anadolu Kaplanları'nın Yükselişi -Türkiye Şehirleşme İncelemesi, Rapor No. 87180TR; http://www.tepav.org.tr/upload/files/14368760088.Anadolu_Kaplanlarinin_Yukselisi_Turkiye_Sehirlesme_Incelemesi.pdf, erişim tarihi 09.08.2018.

Dünya Ekonomik Forumu (WEF), (2017a); "Methodology and Computation of the Global Competitiveness Index 20172018 ; http://www3.weforum.org/docs/GCR20172018/04Backmatter/TheGlobalCompetitivenessReport2017\%E2\%80\%932018AppendixA.pdf, erişim tarihi 06.07.2018.

Dünya Ekonomik Forumu (WEF), (2017b); The Global Competitiveness Report 2017-2018; http://www3.weforum.org/docs/GCR2017-

2018/05FullReport/TheGlobalCompetitivenessReport2017\%E2\%80\%932018.pdf, erişim tarihi 07.07.2018

Dünya Ekonomik Forumu (WEF), (2017c); 2016 The Global Competitiveness Index 2017-2018 edition/Turkey; http://reports.weforum.org/pdf/gci-2017-2018/WEF_GCI_2017_2018_Profile_TUR.pdf, _erişim tarihi 08.08.2018.

Dünya Ekonomik Forumu (WEF), (2018a); The Global The Global Competitiveness Report- Index 4.0; http://www3.weforum.org/docs/GCR2018/05FullReport/TheGlobalCompetitivenessReport2018.pdf, erişim tarihi 09.05.2019.

Dünya Ekonomik Forumu (WEF), (2018b); http://reports.weforum.org/pdf/gci42018/WEF_GCI4_2018_Profile_TUR.pdf erişim tarihi 08.05.2019.

Eroğlu, Osman \& Yalçın, Azmi (2014). "Yeni Bir Rekabet Formu Olan Kent Rekabetçiliğine Yönelik Literatür Taraması", Çankırı Karatekin Üniversitesi İktisadi ve İdari Bilimler Fakültesi Dergisi, 4(1), 19-42, https://dergipark.org.tr/download/article-file/382286, erişim tarihi 14.05.2019.

Henderson, Vernon, Mitra, Arindam (1996). "The New Urban Landscape: Developers and Edge Cities", Regional Science and Urban Economics 26 (1996), 613-643.

https://tr.wikipedia.org/wiki/Hong_Kong, erişim tarihi 01.08.2018.

https://www.finance.senate.gov/imo/media/doc/HRG99-75.pdf, 10.06.2018 
IMD (2018). World Competitiveness Rankings, 2018; https:/www.imd.org/wcc/world-competitiveness-centerrankings/world-digital-competitiveness-rankings-2018/, erişim tarihi 03.05.2019

Kalkınma Bakanlığı (2013). İllerin Sosyo-Ekonomik Gelişmişlik Sıralaması Araştırması (SEGE 2011). Ankara.

Karakılçık, Yusuf (2014). Yeni Bölgeselleşme Politikaları ve Türkiye'de Bölge Yönetimi, Ankara: Seçkin Yayıncılık.

Keleş, Ruşen (2014). Kentleşme Politikası, Ankara: İMGE Kitabevi.

Keleş, Ruşen (2015). Kent, Kentsel Siyaset ve Çevre Yazıları, İstanbul: Arkeoloji ve Sanat Yayınları.

Kitson, Michael, Martin, Ron, Tyler, Peter (2004). "Regional Competitiveness: An Elusive yet Key Concept?". Regional Studies. 38(9): 991-999; https://michaelkitson.files.wordpress.com/2013/02/kitson-marrtin-tyler-rs-2004.pdf, erişim tarihi 31.01.2018.

Koç, Murat, Özbozkurt, Onur Başar (2014). “Ulusların Rekabet Üstünlüğü ve Elmas Modeli Üzerine Bir Değerlendirme”, İşletme ve İktisat Çalışmaları Dergisi, Cilt 2, Sayı 3, ss.85-91 ISSN:2147-804X.

Kumral, Neşe (2008). “Bölgesel Rekabet Gücünü Artırmaya Yönelik Politikalar”, Working Paper No: 08/02, February 2008 Department of Economics Eniversity; https://www.researchgate.net/profile/Nese_Kumral/publication/5012185_Bolgesel_Rekabet_Gucunu_Artirmaya Yonelik_Politikalar/links/5509c2ef0cf26198a639bbf0.pdf, erişim tarihi 31.01.2018.

Lember, Veiko, Kalvet, Tarmo, Kattel, Rainer (2011). "Urban Competitiveness and Public Procurement for Innovation, Urban Studies 48(7), 1373-1395.

Özer, Mehmet Akif (2005). Yeni Kamu Yönetimi, Ankara: Platin Yayınları.

Öztürk, Nazım, Uzun, Meral (2010). "Bölgesel Kalkınma Dinamikleri: Bölgesel Dengesizliklerin Ortaya Çıkmasında Rol Oynayan İktisadi Etmenler”, Celal Bayar Üniversitesi İktisadi ve İdari Bilimler Dergisi, Cilt: 11, Say1:2, 91-110.

Parlak, Bekir (2011). Kamu Yönetimi Sözlüğü, MKM Yayıncılık, Bursa.

Porter, Michael E. (1995). The Competitive Advantage of The Inner City, https://hbr.org/1995/05/the-competitiveadvantage-of-the-inner-city, erişim tarihi 13.05.2019.

Rekabet Derneği (2018). "Rekabet Hakkında" http://www.rekabetdernegi.org/rekabethakkinda.htm, erişim tarihi 30.09.2018.

Sağır Mehmet, Türkeri, İlker, (2015). "Turizm İşletmelerinde Stratejik Boyutları ile Kurumsal Sosyal Sorumluluk: Örnek İncelemeler", Süleyman Demirel Üniversitesi, Sosyal Bilimler Enstitüsü Dergisi, C. 2, S. 22, 283-314; https://dergipark.org.tr/download/article-file/215022, erişim tarihi: 05.05.2019

Sağır, Mehmet (2016). "Sürdürülebilir Turizmde Rekabet Stratejileri”, Turizm Paradigmaları, (Edt: Akgöz Erkan), Detay Yayıncılık, 1. Basım, Ankara, 233-257.

Sağır, Mehmet ve Göktaş, Levent Selman, (2018). "Rekabet İlişkisi İçerisinde Turizm Uygulamaları”, İnsan, Toplum ve Spor Bilimleri Araştırmaları Örnekleri, (Edt. Yamaner Faruk ve Eyuboğlu Ender), Nobel Yayın, 1. Basım, Ankara, 25-47.

Suner, Asuman (1997). "Hong Kong: Sömürgecilik Tarihinde Bir Sayfa Kapanırken”; http://www.birikimdergisi.com/birikim-yazi/2815/hong-kong-somurgecilik-tarihinde-bir-sayfakapanirken\#.W2HDF9Izbs1, erişim tarihi 01.08.2018.

Türk Dil Kurumu (TDK) "Rekabet"; http://www.tdk.gov.tr/index.php?option=com_bts\&arama=kelime\&guid=TDK.GTS.5cd83889bc47c6.95863868, erişim tarihi 15.04.2018

Uluslararası Rekabet Araştırmaları Kurumu (URAK) (2016). İllerarası Rekabetçilik Endeksi (2013-2014); https://drive.google.com/file/d/0BzSH5QdrnBmDdVZSQ2xTbmJCbU0/view, erişim tarihi: 15.12.2018

Uluslararası Rekabet Araştırmaları Kurumu (URAK) (2019). İllerarası Rekabetçilik Endeksi (2018); http://www.urak.org/wp-content/uploads/2019/05/URAK_\%C4\%B0RE_2018-2.pdf, erişim tarihi: 27.05.2019. 